\title{
O DANO MORAL EM CASOS DE MORTE E DE LESÃO CORPORAL *
}

\author{
Jaime Meira do Nascimento Júnior \\ Aluno do Curso de Graduação da Faculdade \\ de Direito da Universidade de São Paulo
}

\begin{abstract}
Resumo:
O trabalho consiste no estudo do dano moral, como forma de lesão a direito subjetivo. O estudo inicia-se pela conceituação do instituto, diferenciando-o do chamado dano material. Em seguida, há uma análise histórica da "iniuria", delito previsto pelo Direito Romano e considerado pelos civilistas como figura jurídica ancestral dos danos morais. No tocante ao problema da reparabilidade ou-não deste tipo de Iesão, faz-se uma breve análise das principais críticas atinentes a este instituto, verificando-se que, em face do Texto Constitucional brasileiro, de 1988, o problema que persiste na atualidade refere-se aos critérios de determinação do "quantum" a ser indenizado. Diante desta consideração e, em face da amplitude do tema, o trabalho passa para o estudo do dano moral no Direito brasileiro com base na lei e na jurisprudência, com enfoque em casos relacionados com morte ou lesão corporal. A análise do instituto termina pelo estudo de outras formas de reparação apresentadas pela doutrina com o intuito de resolver o problema da valoração do dano moral. Em face do presente estudo o autor conclui que, em virtude da falta de objetividade do legislador brasileiro no tocante aos critérios de reparação, o aplicador do Direito deve considerar, sobretudo, o seu aspecto compensatório, deixando o punitivo para um segundo plano.
\end{abstract}

\section{Abstract:}

The work consists in the study of the moral damage, as lesion form to subjective right. The study begins for the definition of the institute, differentiating it of the called material damage. Soon after, there is a historical analysis of the "iniuria", delict foreseen by the Roman Law and considered by many civilists as an ancestral of the moral torts. Concerning to the problem of the reparability or not of this lesion type, a brief analysis of the main critical reporting to this institute is made, being verified that, in face of the brazilian Constitutional Text of 1988 , the problem that persists at the present time refers to the determination approaches of the "quantum" to be reimbursed. Due to this consideration and, in face of the width of the theme, the work passes for the study of the moral damage in the brazilian Law, according to

* O presente trabalho foi apresentado como relatório do Programa Institucional de Iniciação Científica - PIBIC/CNPq - 1997/1998. O autor foi orientado pelo professor doutor Eduardo Cesar Silveira Vita Marchi, titular da Cadeira de Direito Romano da Faculdade de Direito da Universidade de São Paulo. 
the legal texts and the jurisprudence, with focus in cases related with death or corporal lesion. The analysis of the institute finishes by the study of another repair ways presented by the doctrine with the purpose to solving the problem of the value of the moral damage. In face of the present study, the author ends that, by virtue of the lack of objectivity of the brazilian legislator concerning the repair approaches, the applicator of Law, should consider, above all, its compensatory aspect, leaving the punitive for a second plan.

Unitermos: dano moral; responsabilidade civil.

I. Responsabilidade civil e dano. Conceitos e conseqüências.

O dano moral é figura jurídica que se encontra disciplinada no capítulo relativo à responsabilidade civil. Antes, porém, faz-se mister uma breve reflexão a respeito deste tema, para que se possa entender o contexto daquele no quadro da teoria geral do Direito Civil.

Segundo Maria Helena Diniz,' a responsabilidade civil refere-se à imposição a alguém de medida que o obrigue a reparar um dano causado a outrem. Para que esta surja, basta que sejam preenchidos os seus pressupostos, a saber, ação ou omissão qualificada juridicamente, a ocorrência efetiva de um dano, e o nexo de causalidade entre a conduta (ação ou omissão) e a lesão. Aguiar Dias, ${ }^{2}$ a seu turno, explica que, para sua extinção, se faz necessária a reparação efetiva do prejuízo, de modo que se restitua ao lesado o estado existente antes de sua ocorrência.

Mas o que seria exatamente um dano?

Wilson Mello da Silva ${ }^{3}$ definirá dano em sentido amplo como toda lesão a um bem jurídico. Etmologicamente, tal expressão é traduzida como qualquer mal ou ofensa pessoal do qual resulte prejuízo ou deterioração de bens pertencentes a uma pessoa. ${ }^{4}$

Ademais, pela interpretação do art. 159 do Código Civil, infere-se que, para o surgimento de responsabilidade civil, necessária se faz a violação de direito,

1. Curso de Direito Civil Brasileiro, $2^{\mathbf{a}}$ ed., São Paulo, Saraiva, 1986, v. 7, p. 32.

2. Responsabilidade Civil, $10^{\mathrm{a}}$ ed., Rio de Janeiro, Forense, 1997, v. II, p. 713.

3. Silva, Wilson Mello da. O Dano Moral e sua Reparaçāo, Rio de Janeiro, Forense, 1955, p. 11.

4. Garcia, Hamilcar de. Dicionário Contemporâneo da Língua Portuguesa, $3^{a}$ ed., Rio de Janeiro, Ed. Delta, 1980, p. 939. 
ou a ocorrência de prejuízo. De qualquer modo, ambos entrarão no mundo do direito, na medida em que, conforme alude Pontes de Miranda, ${ }^{5}$ efetivamente representarem uma invasão indevida na esfera jurídica da pessoa lesada.

Independerá, pois, da natureza do bem atingido, podendo, inclusive, recair sobre coisa corpórea ou incorpórea.

Desse modo, entende-se por dano a lesão de interesse patrimonial ou extrapatrimonial da vítima que adquire, em função disso, um direito de crédito decorrente da responsabilidade civil (art. 1.518 do Código Civil).

II. Classificação do dano: material e moral.

Segundo Jourdain, ${ }^{6}$ a lesão a um bem jurídico, dentre vários critérios, pode ser classificada em relação ao bem que é atingido.

Justificando tal assertiva, Wilson Mello da Silva ${ }^{7}$ explica que a idéia de dano não se reduz ao universo de prejuízos materiais, mas também pode esta se referir ao desconforto emocional que determinada violação de direito pode produzir.

A seu turno, Pontes de Miranda ${ }^{8}$ identifica um certo tipo de lesão que atinge o patrimônio do indivíduo, e outro que recai sobre o ofendido em sua natureza humana. Nesse sentido, há diferença entre uma situação em que, por culpa ou dolo, uma pessoa destrua um bem físico de terceiro ( $v . g$., casa, carro, computador) em face de outra em que alguém tem sua honra, dignidade ou imagem injustamente atingidas.

Desse modo, fala-se em dano econômico, material ou patrimonial, na primeira situação, e em dano moral ou extrapatrimonial, na segunda.

Portanto, o dano moral não se reflete em um prejuízo físico, mas sim no desconforto emocional que se produz. Isto incute a ele uma característica fundamental, que é a sua amplitude e subjetividade. A dor tanto física quanto moral pode variar de pessoa para pessoa, de modo que cabe apenas a ela dizer quando ocorreu ou-não este tipo de lesão. ${ }^{9}$

Em razão disto, fatos diversos podem gerar uma lesão dessa natureza.

5. Tratado de Direito Privado Direito das Obrigações, Rio de Janeiro, Borsoi, 1966, t. 53, pp. 219 ess. a 126 .

6. Jourdain, Patrick. Les Principes de la Responsabilité Civile, $3^{\text {a }}$ ed., Paris, Dalloz, 1996, pp. 119

7. Id., ibid. (nota 3).

8. Op. cit. (nota 5), p. 231.

9. Silva, op. cit. (nota 3), p. 203. 
Pontes de Miranda ${ }^{10}$ apresenta algumas hipóteses, destacando, in verbis, que "o dano pode consistir em dor física ("Schmerzensgeld"), deformação ("Narbengeld"), afeamento, dor moral (eg., por morte de parentes, vergonha, depressão da energia para a vida), mudança de gênero de vida tornado indispensável, nervosismo oriundo de trauma, diminuição da alegria de viver"

Importante ressaltar que, apesar da diferença entre o dano moral e o material, não se pode afirmar que estes são mutuamente excludentes. É possível, conforme explica Minozzi, " a concorrência de ambos em uma mesma situação.

Isto pode ocorrer, v.g., no caso de protesto indevido de título de crédito já quitado:

Haverá prejuízos materiais, no sentido de que a pessoa lesada, ao justificar e regularizar a sua situação perante os órgãos competentes, terá, v.g., despesas com certidões, cópias autenticadas de documentos, isso sem contar o tempo dispendido nas filas dos cartórios, ou eventuais oportunidades de negócio ou de trabalho que possa perder em razão da existência do protesto.

Ao mesmo tempo, haverá dano moral na medida em que a pessoa, pelo fato de ser injustamente considerada má pagadora perante o mercado, o que implica uma lesão à sua honra (reputação), passa por uma situação constrangedora, o que lhe causa um sofrimento psíquico.

Outro exemplo é o caso do homicídio:

O dano material existe na medida em que haverá custos referentes ao funeral, luto, e, dependendo da situação, a perda da renda oriunda do trabalho da pessoa falecida (damnum emergens e lucrum cessans).

No âmbito moral, a morte representa grande angústia a toda família, podendo resultar traumas psíquicos extremamente dolorosos.

O mesmo ocorre no caso de lesão corporal, visto que, além do custo referente ao tratamento médico da vítima (dano material), haverá todo um sofrimento psíquico (moral) da pessoa atingida e de seus familiares.

10. Tratado de Direito Privado Parte Especial, $3^{\mathrm{a}}$ ed. (reimpressão), Rio de Janeiro, Borsoi, 1971 , t. 26, p. 36.

11. Minozzi, Alfredo. Studio Sul Danno Non Patrimoniale (Danno Morale), $2^{\mathrm{a}}$ ed., Milão, Società Editrice Libraria, 1909, p. 48. 
III. Aspectos históricos: dano moral no Direito Romano.

III. 1. Considerações preliminares: a visão dos estudiosos do dano moral em face do Direito Romano.

Quando se busca estudar algum instituto do Direito Privado, faz-se indispensável uma verificação do legado advindo do Direito Romano, em razão de sua grande influência no pensamento dos juristas até os tempos atuais.

Nesse sentido, vários estudiosos da questão do dano moral ${ }^{12}$ sempre defenderam a idéia da existência de sua reparação no Direito Romano, fundamentando-se, inclusive, com trechos retirados das fontes. ${ }^{13}$

Em verdade, a posição doutrinária predominante é a de que se indenizava o dano moral na maioria dos casos, por meio da chamada actio iniuriarum aestimatoria.

Lúcio Bove, ${ }^{14}$ ao analisar a questão do dano no Direito Romano, conclui que, além do ressarcimento do prejuízo material derivado do ilícito, passou aquele ordenamento, sobretudo após Justiniano, a admitir uma ampliação das diversas hipóteses de indenização.

$\mathrm{E}$ isso se teria dado de tal maneira que essa concessão haveria justificado o reconhecimento do dano moral e a admissão de seu ressarcimento.

Desse modo, o ofendido poderia fazer valer seu direito por meio da actio iniuriarum aestimatoria. ${ }^{15}$

Desse modo, para que se possa compreender o problema do dano moral na atualidade, faz-se mister um breve estudo da injúria (iniuria), considerando-a como sendo o instituto ancestral do dano moral no Direito Romano. Mas antes devemos situá-la dentro da teoria do delito, como fonte das obrigações no

12. A respeito, cf. Salazar, Alcino de Paula. Reparaçäo do Dano Moral, Rio de Janeiro, Borsoi, 1943, p. 13.

13. Cf. El Digesto de Justiniano, trad. espanhol. por A. D'Ors, F. Hernandez-Tejero, P. Fuenteseca, M. Garcia-Garrido e J. Burtillo, Pamplona, Ed. Aranzadi, t. III (Livros 37-50), 1975, p. 641: "Tambien tenemos en nuestro nombre la acción de injuria cuando se hace injuria al cadáver de quien somos herederos civiles o pretorios pues atañe a nuestra dignidad la injuria que se pueda hacer; y lo mismo vale decir quando se difama al cadáver de quien somos herederos." (Ulp. 56 ed. D. $47,10,1,4)$.

14. Bove, Lucio. Danno (Diritto Romano), in Novissimo Digesto Italiano, $3^{\mathbf{a}}$ ed., Turim, Unione Tipografico Editrice Torinese, 1957, t. V, p. 146.

15. A respeito, cf. Silva, Wilson Mello da. Op. cit. (nota 3), p. 13. 
Direito Romano.

\section{2. O delito no Direito Romano.}

Ao elucidar a questão concernente às fontes das Obrigações no Direito Romano, apresenta Girard ${ }^{16}$ a figura jurídica denominada delito (delicta, malefitia). Trata-se de ato ilícito cometido por uma pessoa em prejuízo de outrem.

Tais atos, pelo fato de ocasionarem uma violação no direito de outra pessoa, implicavam para o autor o dever de pagar uma indenização.

Os delitos são classificados como públicos e privados.

Apesar de ambos os tipos acarretarem a imposição de pena a seu autor, no caso dos delitos públicos buscava-se a proteção do interesse geral, enquanto que nos privados se buscava a reparação do dano. ${ }^{17}$

Desse modo, aqueles ocasionavam a imposição de penas corporais e pecuniárias, que não eram revertidas em benefício das vítimas, visto o caráter público da lesão. Implicavam, pois, um procedimento criminal diante dos tribunais especiais, denominados repressivos. ${ }^{18}$

Em oposição, os delitos privados acarretavam penas corporais que, com a evolução do direito, foram se tornando predominantemente pecuniárias.

Este dever surgiu da degradação do direito de vingança privada, de modo a fazer a obrigação recair sobre o patrimônio do autor do ilícito e não mais sobre seu corpo, sobretudo após a edição da chamada lex Poetelia Papiria (326 a. C.). ${ }^{19}$

Tais obrigações eram apreciadas em tribunais civis, mediante ação privada a encargo da vítima, postulando esta o pagamento da indenização para si.

Algumas características terão as obrigações oriundas de atos ilícitos (delitos privados). ${ }^{20}$

16. Girard, Paul Frédéric. Manuel Elementaire de Droit Roman, $4^{\mathrm{a}}$ ed., Paris, Librairie Nouvelle de Droit et de Jurisprudence, 1906, p. 388.

17. Cf. Girard, op. cit. (nota 16), p. 389.

18. Exemplo de delitos públicos no Direito Romano eram os crimina, tais como o parricidium e o perduellio. Cf. Marky, Thomas. Curso Elementar de Direito Romano, $8^{\mathrm{a}}$ ed., São Paulo, Saraiva, 1995, p. 134.

19. A respeito v. Chamoun, Erbert. Instituiçöes de Direito Romano, $5^{\mathrm{a}}$ ed., Rio de Janeiro, Forense, 1968, p. 294.

20. Op. cit. (nota 16), p. 390 
Em primeiro lugar, quanto ao objeto da prestação, após o desaparecimento das penas corporais, todos os direitos subjetivos derivados dos delitos privados passaram a ter por objeto uma soma em dinheiro.

No que tange ao ato ilícito que faz nascer o delito privado, consiste este numa conduta positiva e não apenas uma simples abstenção, expressamente proibida por uma disposição da lei (nulla poena sine lege).

Finalmente, no tocante à pessoa obrigada pelo delito, ela deverá, mesmo no direito mais recente, pertencer a um outro "domus" que não o da vítima, podendo, em contrapartida, ser responsabilizado tanto o sui iuris quanto o in patria potestate; o escravo; a mulher; o louco; e mesmo uma criança (impubere pubertati proximus), esses três últimos se considerados em relação à capacidade de fato. ${ }^{21}$

III. 3. Origem histórica do sistema de delitos privados.

No que toca à questão das origens históricas do sistema de delitos privados em Roma, Girard ${ }^{22}$ argumenta que este, assim como ocorre em instituições paralelas de outros povos, explica-se unicamente como uma etapa da história do Direito Penal.

Nesse sentido, no início da civilização, conforme aludem Silvio Meira $^{23}$ e Moreira Alves, ${ }^{24}$ o Poder Público romano não possuía tamanho alcance e força, a ponto de impor sua vontade em relação aos particulares.

Assim, pode-se identificar quatro fases evolutivas do tratamento jurídico dos delitos privados pelo Direito Romano. Estas apresentam-se da seguinte maneira: vingança privada ou autotutela; composição voluntária; composição obrigatória; e repressão ou vingança pública. ${ }^{25}$

Trata-se a vingança privada da forma mais antiga e imperfeita de repressão à injustiça. Por meio dela, podia o ofendido, de per si, causar um mal a seu agressor, de modo que vingasse a ofensa que houvera sofrido. Não-obstante, podia também a pessoa renunciar a seu uso, chegando até ao perdão. ${ }^{26}$

21. A respeito, cf. Girard, op. cit. (nota 16), p. 391.

22. Id., ibid., nota 21.

23. Instituições de Direito Romano, $3^{\mathrm{a}}$ ed., São Paulo, Max Limonad, 1968, p. 328. 192.

24. Direito Romano, $10^{2}$ ed., revista e acrescentada, Rio de Janeiro, Forense, 1995, v. I, pp. 181 a

25. A respeito, cf., Girard, id., ibid., nota 21.

26. Op. cit. (nota 16), p. 392. 
Nesse sentido, no Direito Romano mais antigo, a autotutela era desmesurada e, mais tarde, a Lei de Talião representou grande avanço, pois a partir de então, o mal seria retribuído com um mal proporcional.

Com o passar do tempo, a vingança privada vai adquirindo um caráter jurídico de modo que, com o passar do tempo, ela acaba por se convergir num segundo modelo pelo qual, mais racionalmente, se atinge a Justiça. Trata-se, pois, da composição voluntária.

Por meio desta, uma vez havendo concordância das partes, era escolhido um terceiro não-pertencente ao Poder Público que fixaria um valor, tendo por escopo compensar o dano ocasionado pelo delito, de modo que o ofensor se tornaria devedor do ofendido. Essa fase também é denominada de arbitramento facultativo. ${ }^{27}$

A vindicta cede passo à pena privada, representando esta a possibilidade de a pessoa lesada escolher, por meio de uma ação judicial, o valor da indenização a ser paga pelo ofensor no caso de um delito privado. ${ }^{28}$

Entretanto, à medida que o Estado romano se consolida como força política e pública, cada vez mais a vítima acaba tendo que se contentar e o ofensor obrigado a pagar uma determinada quantia imposta. Surge, pois, o sistema de composição legal (ou obrigatória) e o ordenamento jurídico passa a repudiar a autotutela de interesses privados.

Segundo Girard, ${ }^{29}$ a Lei das XII Tábuas, v.g., faz perceber a transição que se opera no tocante à injúria, na medida em que a composição já era legal para a injúria por agressões e ferimentos leves e ainda voluntária nos casos de ruptura de um membro.

Finalmente, com a evolução histórica, observou-se, no Direito Romano imperial, uma ampliação do poder estatal, o que implicou a transferência da tutela de determinados ilícitos privados para o campo dos delitos públicos.

O Estado, agora com maior força, retira a composição e impõe a vingança pública (agora feita por meio de agente público), do mesmo modo que outrora repudiara a autotutela.

27. A respeito v. Moreira Alves, op. cit. (nota 24), p. 183.

28. Conforme explicado anteriormente, o ius civile previa na Lei das XII Tábuas quatro tipos de delitos privados: o damnum iniuria datum (dano), a iniuria (injúria), furtum (furto) e rapina (roubo). A respeito, cf. Marky, Thomas. Op. cit. (nota 18), pp. 133 a 138.

29. Op. cit. (nota 16), p. 393. 
Deve-se destacar que a evolução supramencionada ocorreu de maneira lenta, de modo que em diversos momentos os diferentes modelos de apreciação do delito coincidiram, ou seja, coexistiram no tempo para hipóteses diversas.

Assim, v.g., a iniuria, como explicado anteriormente, deixou de ser exclusivamente um delito privado para, mais adiante, ser tutelada em determinados casos (iniuria atrox) pelo ius publicum, para, finalmente, ficar sua disciplina a mercê do Estado imperial.

III. 4. A iniuria como ancestral dos danos morais no Direito Romano.

Segundo Girard, ${ }^{30}$ dentre os delitos privados que acarretam uma pena pecuniária, apresenta-se a injúria como um dos mais importantes.

Explica o autor que, de acordo com o pensamento romano, tratava-se de delito contra a pessoa, não-traduzido por prejuízo pecuniário.

Plescia, ${ }^{31}$ por sua vez, afirma que, etmologicamente, iniuria é uma composição de in e ius, representando a primeira uma partícula negativa e o segundo a idéia de direito, ou algo que liga, de modo que o seu significado relaciona-se a todo ato realizado contra o direito, traduzido num sentido amplo pela violação do direito de outrem seja por escrito, seja oralmente.

A injúria, conforme explicam Correia e Sciascia, ${ }^{32}$ seria a ofensa física ou moral, de qualquer espécie, feita a uma pessoa injustificadamente.

Maynz, ${ }^{33}$ a seu turno, definirá iniuria como tudo o que se faz contrariamente ao direito (quod non iure fit), no sentido de que será todo ato que gere uma lesão física ou moral à personalidade, seja escrita, verbal, enfim, não importando o meio.

Adentrando ao tema, relata Girard ${ }^{34}$ que a injúria, já reprimida na Lei das XII Tábuas, fazia nascer uma ação penal cujas características primitivas mantiveram-se com uma pureza particular.

Nesse sentido, era noxal ${ }^{35}$ - no caso em que o autor do delito fosse

30. Op. cit. (nota 16), p. 398.

31. The Development of "Iniuria". In Labeo - Rasegna di Diritto Romano, Nápoles, Jovene, 1977, v. 23-3, p. 271.

32. Manual de Direito Romano, $2^{a}$ ed., São Paulo, Saraiva, 1953, v. I, p. 367.

33. Cours de Droit Romain, $5^{\text {a }}$ ed., Paris, A. Durant \& Pedone - Lauriel, 1891, p. 470.

34. Id., ibid., nota 26.

35. Pelo regime da noxalidade, o paterfamilias seria responsabilizado pelo ato cometido pelo 
alieni iuris; seria exercida cumulativamente contra os autores do delito em caso de pluralidade; e não-passava aos herdeiros do autor do delito, ${ }^{36}$ sendo, porém, uma das raras ações que se extinguiam pela morte da vítima. ${ }^{37}$

De resto, explica Girard ${ }^{38}$ que a determinação dos casos em que ocorre tal delito, bem como sua disciplina jurídica, variaram conforme o período histórico. Desse modo, distinguirá o regime estabelecido pela Lex XII Tabularum (1), pela Actio Iniuriarum Aestimatoria (2), pela Lex Cornelia de Iniuriis (3), e a do Direito Imperial(4).

(1). A Lei das XII Tábuas considerava a injúria apenas em algumas situações enumeradas, sobretudo no que se refere aos atentados contra a pessoa física. As hipóteses por ela elencadas eram, a saber, a ruptura de um membro (membrum ruptum), a fratura de um osso (os fractum) e algumas injúrias ordinárias lesão corporal leve ou vias de fato consideradas de acordo com o autor, como, v.g., um soco.

No tocante à repressão da injúria, conforme explica o mesmo autor, ${ }^{39} \mathrm{a}$ lex marcaria uma fase de evolução da apreciação deste delito, no sentido de que, para determinadas situações, tais como o rompimento de um membro, ainda se admitia a vingança privada, enquanto que, para outros, a composição voluntária ou até mesmo a legal. ${ }^{40}$

Além disso, segundo Correia e Sciascia, ${ }^{41}$ previa a Lex XII Tabularum penas pecuniárias. Assim, v.g., para o osso quebrado (os fractum), trezentos asses, se a pessoa lesada fosse livre; 150, sendo escrava; 25 asses para os casos de iniuria simples.

filiusfamilias, ou pelo escravo, ou fato de animal. Havia então duas possibilidades para aquele: pagar o valor a que seria condenado; ou abandonar o filiusfamilias, que se tornaria pessoa in mancipio; ou o escravo, ou o animal em favor da vítima, que se tornaria proprietária deles (a respeito, v. Moreira Alves, José Carlos. Direito Romano, $3^{\mathrm{a}}$ ed., Rio de Janeiro, Forense, 1980, v. II, p. 266). Ainda no que toca à noxalidade da iniuria, cf. Vigorita, Tulio Spagnuolo. Actio Iniuriarum Noxalis. In Labeo Rassegna di Diritto Romano, Nápoles, Jovene, 1969, v. 15-1, pp. 33 a 76.

36. A respeito, vide Simone, Enrico de. D. 47.10.1.6-7. In Labeo - Rassegna di Diritto Romano, Nápoles, Jovene, 1966, v. 12-3, pp. 355 a 357.

37. A respeito v. Gaio, 4. 76; Gai. 13 ed. prov. D. 47, 10, 34; e Gaio, 4. 112.

38. Op. cit. (nota 16), p. 399

39. Id., ibid., nota 32 .

40. A respeito, v. comentários anteriores a respeito das origens históricas dos delitos privados.

41. Op. cit. (nota 32), p. 367. 
(2). Num segundo momento, o pretor, por meio de seu interdito, modificou tanto a pena quanto a definição do delito. Conservou, pois, os antigos casos, acrescendo-lhes novas situações advindas do desenvolvimento da doutrina, que passou a encarar a injúria como todo atentado físico ou moral à personalidade.

No tocante à repressão, decidiram os pretores pela generalização da composição legal. Porém entenderam que as penas discriminadas pela Lei das XII Tábuas já não mais atendiam ao objetivo de punição, sobretudo após o crescimento das fortunas e da redução sucessiva do valor do "as"

Desse modo, a antiga ação do ius civile foi substituída por uma ação pretoriana in bonum et equum conceptum, pela qual o montante a ser pago era avaliado de acordo com o caso concreto e cuja condenação acarretava a infamia. A actio iniuriarum acabou tornando-se, então, aestimatoria. Tal reforma, com exceção dos casos que envolviam peregrinos, somente operou-se após o surgimento da Lex Aebutia (séc. II a. C.).

No tocante à determinação do quantum debeatur, explicam Correia e Sciascia $^{42}$ que as circunstâncias de tempo, lugar, qualidade das pessoas passaram a ser levadas em consideração na actio iniuriarum aestimatoria. Tal ação, porém, deveria ser intentada em até um ano da data da ocorrência do fato.

Ademais, segundo Maynz, ${ }^{43}$ por meio dessa actio, a pessoa injuriada poderia ela mesma estimar o valor da reparação pecuniária.

Em oposição, havia também a actio iniuriarum contraria, destinada a punir todo aquele que tivesse acionado alguém por injúria temerariamente. ${ }^{44}$

(3). O terceiro período concernente ao tratamento do delito da injúria foi o da Lex Cornelia de Iniuriis. Esta separou das outras injúrias as lesões e a violação de domicílio (pulsare, verberare, vir domum introire) dando-lhes natureza de delito público, provavelmente em conformidade com uma quaestio perpetua, permitindo submetê-las ainda à actio iniuriarum aestimatoria. ${ }^{45}$

Explica Maynz ${ }^{46}$ que a Lex Cornelia dava a oportunidade de a pessoa

42. Id., ibid., nota 41 .

43. Id., ibid., nota 33 .

44. A respeito vide Serangeli, Sandro. C. 7, 16, 31 e Le Azioni Contro Il Litigante Temerario. In Bulletino Dell'Istituto di Diritto Romano "Vittorio Scialoja", Milão, Dott. A. Giuffrè Editore Milano, terceira série, 1968, v. X (v. LXXI da coleção inteira), pp. 199 a 226

45. A respeito, vide Marcian. 14 instit. D. 47, 10, 37.

46. Id., ibid., nota 33 . 
escolher entre a aplicação de uma pena privada ou a perquirição criminal diante de um tribunal permanente e especial, só cabendo esta à pessoa injuriada.

Ademais, segundo o mesmo autor, tal actio teria caráter perpétuo. ${ }^{47}$ Interessante notar que, em sentido oposto, explicam Correia e Sciascia ${ }^{48}$ que a actio ex lege Cornelia ${ }^{49}$ prescrevia em trinta anos.

(4). Finalmente o Direito imperial manteve a tendência no sentido de atribuir uma repressão pública, tal como iniciada pela Lex Cornelia. Deu a todos os casos a possibilidade de a vítima escolher entre a ação de injúria e uma punição física infligida ao culpado extraordinem pelo magistrado. ${ }^{50}$

De qualquer modo, pode-se perceber que o Direito Romano aplicou um tratamento, em princípio, punitivo ao delito da injúria. Entretanto, em determinadas situações, havia momentos em que o legislador dava uma certa margem para que a parte ofendida estimasse um valor para a ofensa que sofresse, de modo que para o autor surgisse o dever de indenizar.

A partir desta constatação, defende-se a idéia da existência de indenização do dano moral no Direito Romano, sem porém afirmar-se categoricamente que os juristas romanos tivessem consciência disso.

Certo é que as fontes apresentavam-se contraditórias a respeito da questão da estimação do preço da dor, ${ }^{51}$ porém não se pode negar que aquele ordenamento admitiu em determinado período uma indenização pela agressão à honra, seja física ou moral, a título de pena privada ou pública, o que serve de base para um estudo do problema do dano moral no Direito Civil moderno.

47. Segundo Moreira Alves, id., ibid. (nota 35), as ações que sancionavam os delitos privados (sobretudo as previstas pelo ius civile) eram perpétuas, enquanto que as ações pretorianas deveriam ser invocadas dentro de até um ano da ocorrência do ato ilícito. Assim, perpétua é a ação que não possui prazo de prescrição.

48. Id., ibid., nota 41 .

49. A respeito, vide G. 3, 220-225; G. 4, 112; G. 4, 117; e G. 4, 182.

50. A respeito, vide Hermog. 5 <iur.> epit. D.47.10.45.

51. A respeito, vide Gai. 6 ed. prov. D. 9, 3, 7: "cicatricum autem aut deformitatis nulla fit aestimatio quia liberum corpus nulla recipit aestimationem" (porém nenhuma estimação se faz da cicatriz ou da deformidade porque o corpo de uma pessoa livre não-comporta estimação). 
IV. Problemas atinentes à reparação civil do dano moral.

Pontes de Miranda, ${ }^{52}$ ao estudar o tema, ressalta que nas pretensões oriundas de dano moral, ao contrário do que ocorre com o material, surgem algumas dificuldades, sobretudo no que toca a determinação do valor da indenização.

Dúvidas como esta foram argüidas pela doutrina, não faltando autores que fossem contra a qualquer tipo de indenização aos danos daquela natureza.

$\mathrm{Na}$ doutrina pátria, Lacerda de Almeida ${ }^{53}$ foi o maior representante da teoria negativista, afirmando categoricamente a não-existência de reparação de outro dano que não o patrimonial no Direito brasileiro. Sobre este tema escreve o autor, in verbis: "Ainda não me pude convencer da existência de damno civil de ordem não patrimonial. As coisas inestimaveis repellem a sanç̧ão do Direito Civil que com ellas não se occupa, e, se alguma vez entram em linha de conta com o valor de estimação, ou qualquer outra espécie de damno, tem de baixar da região superior onde paira e soffrer a simples avaliação em moeda das cousas venais" 54

$\mathrm{Na}$ Alemanha, Savigny ${ }^{55}$ entendia que as prerrogativas do ser humano não estariam previstas no domínio do Direito Privado.

Finalmente, no Direito italiano pode-se citar Gabba ${ }^{56}$ que, ao defender a tese da não-reparabilidade do dano moral, elencou diversos problemas que geraram todo um debate a respeito do tema e que serão o objeto de estudo deste tópico.

IV 1. Impropriedade da expressão dano moral.

O fundamento da presente crítica refere-se ao fato de que, segundo Gabba, ${ }^{57}$ para se admitir a existência de uma lesão, necessária é a ocorrência de uma diminuição durável do valor de um bem. E na situação em estudo, ao invés de existir um "dano moral" surge apenas uma "ofensa". E não há que se confundir ofensa com

52. Op. cit. (nota 5), p. 229.

53. Obrigações, $2^{a}$ ed., São Paulo, Typographia Revista dos Tribunais, 1916, p. 281 e nota 14 bis.

54. Id., Ibid., nota 53.

55. Système de Droit Romain. 330. Apud Mendonça, Manuel Ignacio Carvalho de. Doutrina e Prática das Obrigações ou Tratado dos Direitos de Crédito, $3^{\mathrm{a}}$ ed., Rio de Janeiro, Livraria Editora Freitas Bastos, 1938, v. II, p. 443, in nota 71.

56. Risarcibilità dei danni morali, in Questioni di Diritto Civile - Diritto Ereditario e Diritto delle Obligazioni, $2^{\mathrm{a}}$ ed., Torino, Fratelli Bocca Editore, 1911, v. II, pp. 210 a 246.

57. Gabba, op. cit. (nota 56), pp. 230 e 231. 
dano, visto que o fundamento deste é a existência de um efeito penoso durável, enquanto que, naquela, o efeito, apesar de poder ser mais ou menos durável, sempre terá um caráter passageiro. Desse modo, a expressão "dano moral" torna-se vaga e o que existe na realidade é uma "ofensa moral"

Minozzi ${ }^{58}$ rebaterá tal assertiva, afirmando que a existência jurídica do dano relaciona-se apenas com ocorrência de um prejuízo, seja material, ou moral, pouco importando sua duração.

Antunes Varella, ${ }^{59}$ explicando melhor a questão, afirma que dano é toda lesão a interesse jurídico alheio tutelado pelo ordenamento jurídico, independentemente deste atingir o âmbito patrimonial ou moral.

Desse modo, o dano não é algo relacionado com sua maior ou menor duração, mas sim com a própria lesão cometida em face da esfera jurídica de outrem. Portanto, não há problema algum em se empregar a expressão "dano moral"

IV. 2. Incerteza acerca da existência de um direito violado. ${ }^{60}$

Outra questão refere-se à incerteza acerca da existência de um "bem moral" violado. Surge, então a seguinte dúvida: como se prova a efetiva ocorrência de um dano moral? Deveria o aplicador do direito, antes de falar em indenizar o dano moral, preocupar-se com sua efetiva existência, bem como no que consistiria o dano violado.

Concorda Minozzi ${ }^{61}$ que se deve verificar tal requisito, mas não admite ser essa dificuldade de comprovação uma negativa de indenização para todos os casos dessa matéria. Afinal, é sabido que de uma mesma situação podem surgir, simultaneamente, danos de natureza patrimonial e moral.

Portanto, nada impede, pois, que o juiz, diante do caso concreto, seja capaz de identificar a efetiva ocorrência ou-não de um dano extrapatrimonial. ${ }^{62}$

Desse modo, melhor que o legislador parta, primeiramente, da

58. Op. cit. (nota 11), p. 48.

59. Direito das Obrigaçōes, Rio de Janeiro, Forense, v. 1, 1977, p. 240.

60. Gabba, op. cit. (nota 56), p. 226.

61. Op. cit. (nota 11), p. 50 e 51 .

62. Nesse sentido o autor (id., ibid., nota 11) afirma, in verbis: "Il danno morale, ripetiamo, non è l'astratta lesione di diritto, ma l'effeto non patrimoniale di una lesione di diritto." (...) "La injuria (causa del danno) non è materiale o morale, come o vorebbe il Chironi: esse giuridicamente è sempre una sia materiale o morale, patrimoniale o non patrimoniale il bene o il diritto leso" 
possibilidade de indenizar o dano não-patrimonial, para depois deixar que o aplicador do direito cogite de sua existência no fato concreto.

Assim, a existência ou-não da lesão moral será averiguada na realidade factual, o que não seria possível caso fosse de pronto reputada irreparável. ${ }^{63}$

\section{3. Dano moral: enriquecimento sem causa?}

Parte da doutrina que nega a existência de um dano não-patrimonial reputa que sua reparação implicaria um enriquecimento sem causa.

Nesse sentido, Alfred Martin, ${ }^{64}$ ao discutir esta questão, afirma que um benefício pecuniário atribuído à injúria recebida não-satisfazem nem ao direito e nem à lógica.

Ora, conforme explica Martin-Achard, ${ }^{65}$ é indiscutível que, nos casos de danos morais, sofre o prejudicado uma lesão que atinge o seu direito de personalidade. Nada melhor do que uma indenização que vise a suprir essa dor sentida.

Não se trata de um pagamento sem motivação, mas sim de uma maneira de compensar, pelo dinheiro, a perda, a lesão ao bem-estar, à honra, ao decoro e à imagem da pessoa. Destarte, não seria um enriquecimento sem causa, mas apenas um legítimo ressarcimento.

IV. 4. Impossibilidade de se estabelecer uma proporção entre culpa e indenização.

Segundo Gabba, ${ }^{66}$ reparabilidade dos danos morais ocasionaria verdadeira ruína à teoria geral do Direito Civil. Isto porque nessa hipótese de dano não se poderia estabelecer uma proporcionalidade entre culpa e ressarcimento.

Minozzi $^{67}$ rebate essa argumentação de Gabba explicando que a mesma teoria geral do dano também prevê, sem nenhum problema, a possibilidade de uına responsabilidade sem culpa - o que implica a total desconsideração daquela proporcionalidade.

63. Id., ibid., nota 11 .

64. De la responsabilité résultant des délits d'après le Code fédéral des Obligations, in Zeitschrift für schweizerisches Recht, Bale, 1889, v. VIII, pp. I e ss. Apud Martin-Achard, id., ibid., nota 65.

65. De la Réparation Pécunicire du Tort Moral, Genebra, Livraria Künding, 1908, p. 177.

66. Op. cit. (nota 56), p. 237.

67. Minozzi, op. cit. (nota 11), p. 73. 
No mesmo sentido, Pontes de Miranda ${ }^{68}$ é bem claro ao afirmar a existência da chamada responsabilidade objetiva, advinda do simples nexo causal entre o ato ilícito e a ocorrência do dano, sem que se cogite de culpa.

Desse modo, assim como qualquer outro dano, o não-patrimonial apresenta-se como conseqüência de um ato contra ius e pode ter a sua responsabilidade oriunda do simples nexo causal entre a ofensa moral e a dor ou sofrimento dela decorrente.

IV 5. Inconvenientes nos casos de pluralidade de sujeitos ativos.

Outra objeção atinente à reparação do dano moral refere-se ao inconveniente que se verificaria nos casos de pluralidade de sujeitos ativos. Assim, segundo exemplifica França, ${ }^{69}$ como e quem indenizar num caso de homicídio, em que a vítima possuísse diversos parentes e amigos? Cada um poderia alegar uma determinada pretensão indenizatória? Como se pode ver, o problema reside na indeterminação do número de pessoas prejudicadas e com pretensão indenizatória.

Minozzi $^{70}$ critica tal argumentação e diz que o problema da indeterminação que esta pluralidade de sujeitos ocasiona pode existir em qualquer tipo de dano.

Assim, v.g., se alguém causa um prejuízo material que recai diretamente sobre Tício, este pode repercutir na vida de seus familiares, amigos ou credores.

No entanto, ao invés de, diante dessa situação, o ordenamento jurídico negar-lhe qualquer tutela, estabelece, por intermédio da lei e dos princípios gerais do direito, quem será ressarcido. Assim, no exemplo supramencionado, terá Tício a pretensão à indenização, com base no art. 159 do Código Civil, combinado com o 1.518 .

Aplicando tal raciocínio ao dano moral, Wilson Mello da Silva ${ }^{71}$ propõe que a solução desse problema pode se dar pela adoção de uma presunção,

68. Para uma melhor compreensão a respeito das fontes da responsabilidade civil, cf. Pontes de Miranda, Tratado de Direito Privado (op. cit., nota 5), t. II, pp. 187 e ss.

69. França, Limongi. Reparação do Dano Moral, in Revista dos Tribunais, São Paulo, Revista dos Tribunais, v. 631 , maio-1988, p. 33.

70. Op. cit. (nota 11), p. 74.

7I. Mello da Silva, Wilson, in Enciclopédia Saraiva do Direito, p. 274. Apud França, Limongi. Id., ibid., nota 69 
sempre iuris tantum, de ocorrência do prejuízo para um estrito círculo de relações da família (filhos, pais, irmãos), cabendo aos terceiros (primos, amigos) a prova, quantum satis, de que efetivamente sofreram danos.

Outra solução, talvez mais restritiva, seria a delimitação legal de quais pessoas poderiam pleitear tal direito. Assim, v.g., no caso de homicídio, os herdeiros necessários.

De qualquer modo, determinante para a identificação dos sujeitos ativos será a análise do caso concreto. E esta é a atribuição do juiz que, de acordo com a casuística, identificará aqueles que serão merecedores ou-não desta indenização. O que importa ressaltar é que, em face do Direito Positivo, não se deve restringir tal possibilidade ao aplicador do direito.

IV. 6. Dano moral: pena ou indenização $?^{72}$

Passou-se então a defender a tese de que a indenização do dano nãopatrimonial tivesse um caráter penal (punitivo), e não-compensatório num sentido civilístico.

Nesse sentido, escreve Carbonnier" ${ }^{73}$ que "(...) los daños y perjuicios [morales] se configuran entonces como una suerte de pena privada que, en lugar de beneficiar al Estado, como la multa del Derecho Penal, aprovecha a la víctima $(\ldots) "$

$\mathrm{Gabba}^{74}$ vai mais além e defende essa tese, citando, primeiramente, o art. 38 do Código Penal italiano, afirmando não se poder confundir ressarcimento de dano moral com a pena prevista na legislação. Assim sendo, tomando-se a premissa de que a reparação do dano moral visaria à punição da pessoa que o cometer, tendo por beneficiária a própria vítima, não se poderia tomá-lo como uma espécie de pena privada, no sentido de uma vingança autorizada pelo Estado?

Minozzi ${ }^{75}$ discorda e afirma que, no decorrer da história do Direito,

72. Gabba, op. cit. (nota 56), pp. 215 a 218.

73. Carbonier, Jean. Derecho Civil Situaciones Extracontratuales y Dinámica de las Obligaciones. Trad. Manuel Maria Zorrilla Ruiz. Barcelona, Bosch - Casa Editorial, 1971, t. II, v. III, pp. 65 e 66.

74. Segundo Gabba (op. cit., nota 56, p. 215), o art. 38 estatui que "(...) oltre alle restituzioni e al risarcimento dei danni, il giudice, per ogni delitto che offenda l'onore della persona o della famiglia, ancorchè non abbia cagionato danno, può assegnare alla parte ofeesa una somma determinata a titulo di riparazione (...)"

75. Op. cit. (nota 11), p. 65. 
havia momentos em que a pena e a reparação do dano confundiam-se e que a evolução do instituto tinha lhe dado, na atualidade, um caráter de reparação civil. Desse modo, indenizar o dano moral não seria uma "punição" mas sim um "ressarcimento"

Certo é que, hodiernamente, a idéia de pena refere-se a um escopo de prevenção e intimidação, enquanto que a reparação civil visa à atribuição ao lesado de uma soma, de uma vantagem econômica a título de indenização (ressarcimento) satisfatória em face do dano sofrido. Em última análise, enquanto que na pena se busca punir, na reparação civil procura-se restituir ao lesado uma situação de direito próxima à anteriormente existente.

Nesse sentido, baseando-se em Fischer, ${ }^{76}$ é possível elencar algumas diferenças entre pena e reparação, a saber:

a. a pena está relacionada com a culpa do delinqüente, enquanto a indenização atende à preocupação de reparar o dano;

b. a pena é sempre consequiência de um delito tipificado, enquanto a indenização tem no ato ilícito uma de suas possíveis fontes; ${ }^{77}$

c. a pena é inseparável da pessoa do delinquiente, enquanto que o dever de indenizar pode ser transferido aos herdeiros do responsável;

d. o menor inimputável não está sujeito à pena, enquanto que o menor relativamente incapaz pode ser responsabilizado nos termos do art. 156 do Código Civil;

e. o dever de reparar o dano pode advir de responsabilidade objetiva e a doutrina majoritária repudia a idéia de punição sem culpa.

Ademais, com o surgimento do Estado moderno, a idéia de pena privada entrou em conflito com a soberania daquele, de modo que adquiriu um caráter excepcional. ${ }^{78}$ A História fez com que, tal e qual ocorreu no caso da injúria, o aspecto punitivo de qualquer ato ilícito ficasse, como regra geral, a mercê do Direito Público, ${ }^{79}$ enquanto que a vertente satisfativa continuasse na orla do Direito Civil.

76. A reparação dos danos no Direito Civil, São Paulo, Saraiva, 1938, pp. 228 a 233.

77. Id. ibid. (nota 76).

78. A respeito, cf. Aguiar Dias, op. cit. (nota 2), p. 733, em que o autor admite a existência, em caráter excepcional, de pena civil no Direito brasileiro (art. 1.530 do Código Civil).

79. Exemplo disso, são os chamados Crimes Contra a Honra (arts. 138 a 141 do Código Penal), previstos na lei penal brasileira. 
Por esta razão, entende $\operatorname{Minozzi}^{80}$ que não se pode atribuir à indenização do dano não-patrimonial o caráter de "pena" somente porque teve em sua origem histórica a qualidade de pena privada.

A própria evolução do Direito determina, então, o seu aspecto de ressarcimento, sem que se exclua a apreciação do mesmo fato no âmbito do Direito Penal. $^{81}$

De qualquer modo, os limites entre essas duas vertentes variaram conforme a história de cada povo, prevalecendo, no âmbito do Direito Civil moderno o aspecto compensatório do dano moral, tendo em vista o restabelecimento do direito lesado. ${ }^{82}$

E qual a diferença prática em se considerar o dano moral uma reparação civil, ao invés de uma pena? Basta observar as conseqüências.

Supondo-se que se trate de punição, deverá o juiz aplicá-la restritivamente, em face de expressa previsão legal, uma vez que, em nosso ordenamento, vigora o princípio da nulla poena sine lege. Isto implicará um entrave para a consideração do dano moral na medida em que, mesmo se for considerado uma pena civil, o juiz não poderá utilizar-se de recursos tais como a analogia.

Em contrapartida, considerando-se a indenização do dano moral como reparação, haverá vantagens, sobretudo, tendo em vista a maior liberdade que terá o juiz para apreciar o caso concreto e estabelecer um montante justo para a fixação do dano.

Ademais, é impossível que a lei preveja todas as hipóteses de dano moral e, para que se tenha uma idéia da mentalidade do legislador brasileiro, a Constituição Federal, de 1988, em seu art. $5^{\circ}$, incisos V e X, determina uma ampla margem de indenização deste tipo de ilícito.

Entretanto, deve-se destacar que, como se trata de "reparação" a fixação deste quantum deve buscar produzir uma satisfação à pessoa lesada equivalente ao sofrimento vivenciado e não um mal proporcional ao agente causador do dano. Não se trata, assim, de uma forma de vingança nos moldes da Lei de Talião. O que se vislumbra é a compensação ao mal injustamente sofrido.

80. Op. cit. (nota 11), p. 68 .

81. Assim reza o art. 1.527 do Código Civil brasileiro: "A responsabilidade civil é independente da criminal; não se poderá, porém, questionar mais sobre a existência do fato, ou quem seja o seu autor, quando estas questões se acharem decidas no crime"

82. Aguiar Dias, op. cit. (nota 2), p. 735. 
Assim, v.g., se um grande jornal desrespeitar a imagem de uma pessoa, apresentando declarações que atinjam o público de uma grande cidade, pagará indenização equivalente a outro, de menor tamanho, que causar um dano semelhante.

Deve-se repudiar uma indenização que esteja tão-somente vinculada ao agente que causou o dano, uma vez que isto seria apenas uma forma de punição. Deve o causador do dano pagar uma quantia que proporcione ao ofendido condições para se refazer da dor emocional que tenha sofrido.

IV 7 Imoralidade de se compensar dor pelo dinheiro e a refutação filosófica de sua reparação. ${ }^{83}$

Falam os opositores da imoralidade de se compensar a dor pelo dinheiro. Tais críticas apresentam-se, conforme explica Martin-Achard, ${ }^{84}$ presentes sobretudo na doutrina alemã de fins do século XIX.

Nesse sentido, Reiffel ${ }^{85}$ fala que um homem que sabe caminhar no mundo sem mendigar não pode aceitar tal indenização. Hartmann, ${ }^{86}$ a seu turno, explica que as decisões que permitissem perdas e danos a esse tipo de delito (moral) não encontrariam respaldo no "sentimento do povo alemão"

Finalmente, segundo Gabba, ${ }^{87}$ não se poderia pagar pela vida de um marido ou pai. Não haveria que se fazer uma especulação monetária de sua morte.

Quanto a isso, Minozzi ${ }^{88}$ afirma que existe uma confusão em tal linha de raciocínio. É claro que os bens morais (vida, integridade física, liberdade, honra) não podem ser cedidos mediante paga. Não há como se estabelecer um preço a um dano dessa natureza, visto que não é possível determinar um valor de troca, tal e qual ocorre nos danos materiais, problema este já discutido quando analisada a questão da equivalência no Direito Civil.

Entretanto, o objetivo da reparação dos danos morais não é o pagamento de um preço. O que se busca, sempre dentro da sistemática da reparação,

83. Gabba, op. cit. (nota 56), p. 223.

84. Op. cit. (nota 65), p. 170.

85. Ersatz des moralischen Schaden Zeitschrift für französiches Recht, v. XX, pp. 691 e ss. Apud Martin-Achard, op. cit. (nota 65), p. 170. 170.

86. Archiv. fuir die Civilische Praxis, 1888, p. 364. Apud Martin-Achard, op. cit. (nota 65), p.

87. Id., ibid. nota 66 .

88. Op. cit. (nota I1), p. 75. 
é tentar reduzir, ao menos em parte, a turbação sofrida. É certo que não há como se realizar uma reparação perfeita, visto a imaterialidade do dano moral. Todavia, quando se admite a indenização ao prejudicado, resguarda-se sua personalidade contra um penoso atentado.

No mesmo sentido, Martin-Achard ${ }^{89}$ refuta com veemência o argumento dos juristas alemães. Segundo o autor, pensando conforme a mesma "moral da sociedade" ninguém criticaria o pagamento de honorários ao médico que salva a vida do paciente; não se reclamaria caso alguém recompensasse uma pessoa que se jogou ao mar para salvar a vida de um homem que se afoga; ou que encontrasse um objeto de arte, ou papéis de uma familia. Ora, se a moral encoraja o pagamento a serviços imateriais, que problema haveria caso o objeto do pagamento se referisse à reparação desses bens?

Dessa maneira, acompanhando a opinião de Minozzi, Martin-Achard ${ }^{90}$ entende que não se pode afirmar a existência de imoralidade pela impossibilidade de equivalência entre dinheiro e dano.

Deve-se tão-somente buscar a satisfação de modo que se compense a dor sofrida injustamente e não se permita que o ordenamento jurídico ignore a existência dos bens não-patrimoniais.

Assim, mais imoral que a reparação dos danos morais é o seu afastamento da órbita jurídica. Tal indenização precisa ser cada vez desenvolvida mais paralelamente ao dano material, de modo a se atingir mais casos. ${ }^{91}$

IV 8. Danos indenizáveis e não-indenizáveis.

A doutrina também prevê a aceitação parcial da reparação dos danos morais, de acordo com alguns critérios.

Assim, Matthias ${ }^{92}$ fala em bens não pecuniários passíveis de uma estimação geral e objetiva, como a vida, honra, imagem e saúde - indenizáveis -, e dos bens não-pecuniários de valor puramente subjetivos - não-reparáveis pecuniariamente.

89. Op. cit. (nota 65), p. 173.

90. Op. cit. (nota 65), p. 174.

91. Martin-Achard, op. cit. (nota 65), p. 176.

92. Lehrbuch des Bürgerlichen Gesetzbucher, Berlim, 1900, § 847. Apud Martin-Achard, op. cit. (nota 65), p. 185. 
No mesmo sentido, Chironi ${ }^{93}$ admitindo-a apenas se o dano fosse suscetível de estimação pecuniária.

Aubry e Rau, ${ }^{94}$ por sua vez, entendem ser indenizável apenas o dano moral que também fosse considerado um delito penal.

Von Tuhr, ${ }^{95}$ ao seu turno, defende a reparabilidade de danos nãopatrimoniais relativos aos chamados direitos da personalidade, a saber, a honra, a imagem, o bom nome no comércio. Entretanto, nos casos de morte ou de lesão corporal (incluindo neste o dano estético), verifica-se que o autor fala apenas em reparação das despesas patrimoniais obtidas com enterro (no primeiro caso) ou tratamento médico e invalidez (no segundo).

Criticando esta última posição, Capitant e $\operatorname{Colin}^{96}$ afirmam que uma vez um acidente cause a morte de uma pessoa, o fato acarreta aos seus próprios parentes um direito a indenização pela perda de afeição, ou seja, a dor que lhes causou o desaparecimento de um ente querido. No mesmo sentido, a dor física causada à vítima em razão de ferimentos, no caso o pretium doloris, deve ser levada em conta para calcular o montante da indenização.

Carvalho de Mendonça, ${ }^{97}$ a seu turno, critica Aubry e Rau, afirmando que a opinião deles origina-se de uma idéia antiga que encarava o dever de reparação mais como pena contra o culpado, do que como compensação. Nesse caso, faz sentido só considerar-se dano moral indenizável o previsto na lei penal. Entretanto, conforme visto anteriormente, existe grande diferença entre pena e reparação, o que denota uma flagrante confusão dos autores franceses.

Em razão de toda essa diversidade de opiniões, Martin-Achard ${ }^{98}$ critica aqueles que tentam arbitrariamente classificar quais danos devem ou-não ser indenizáveis.

Entende o autor pela necessidade de se atribuir ao juiz, em face do

93. La Colpa nel Diritto Civile Odierno (Colpa extra-contrattuale), $2^{\mathrm{a}}$ ed., Turim, Fratello Bocca Editori, 1906, v. II, p. 329.

94. Cours de Droit Civil français, Paris, Imprimerie et Librairie Generale de Jurisprudence Marchal et Billard, 1920, t. VI, pp. 345 e 346.

95. Tratado de las Obligaciones. Trad. do alemão por W, Roces, $1^{2}$ ed., Madri, Editorial Reus S/A, 1934, t. 1, pp. 266 e 267.

96. Cours Elémentaire de Droit Civil français, 2ª ed., Paris, Librairie Dalloz, 1953, t. III, p. 213.

97. Op. cit. (nota 55), p. 446.

98. Martin-Achard, op. cit. (nota 65) p. 182. 
caso concreto, a determinação do valor a ser indenizado, uma vez existindo violação ou lesão de ordem moral.

Isso porque, não-obstante a dificuldade de se identificar o valor de afeição ("Schmerzensgeld") de determinadas lesões, nenhuma das teorias que tentaram classificar os danos apresentou critérios totalmente objetivos e isentos de questionamento.

Afirma, in verbis, que: "Limiter d'avance et selon des régles fixes, la protection juridique à certains intérêts, nous paraît une mesure dangereuse et peu conforme à l'esprit du droit moderne. 99

Desse modo, não deve a doutrina definir o que é ou-não indenizável, mas sim as contingências do caso concreto a serem verificadas pelo magistrado.

IV 9. Inconvenientes sobre um excessivo arbítrio atribuído ao juiz. ${ }^{100}$

De acordo com a presente crítica, reparar o dano moral implica o risco de, em decorrência de um excessivo arbítrio do juiz, surgirem decisões arbitrárias, a ponto de se chegar o dia em que será concebido uma verdadeira indústria dos danos morais. O consenso de qualquer tribunal acerca do valor do dano moral acabaria por ser fruto de uma mera estipulação, não-traduzindo um valor justo que se lhe deveria imputar.

Nesse sentido pode-se citar o caso da Justiça maranhense que, no início de 1997, determinou que o Banco do Brasil pagasse uma indenização de $R \$$ 255,5 milhões a um empresário que teve um cheque indevidamente devolvido em 1988. O autor alegava que o ocorrido fez com que ele perdesse crédito junto ao meio comercial, após a inclusão de seu nome junto ao Serviço Central de Proteção ao Crédito (SCPC). Isso, mais tarde, teria levado sua empresa à falência. O juiz que prolatou a sentença, tendo em vista a resistência da instituição financeira em pagar tal quantia, mandou arrombar os cofres do Banco. ${ }^{101}$

Interessante notar que tal questão não é desconhecida e sequer negada pelos autores que aceitam a reparabilidade dos danos não-patrimoniais. Assim, v.g., entende Laurent ${ }^{102}$ que, apesar de o juiz não poder atribuir uma indenização exata,

99. Martin-Achard, op. cit. (nota 65), p. 186.

100. Gabba, op. cit. (nota 56), p. 254.

101. A respeito vide Aith, Marcio. "Maranhão tem Indústria de Indenização" in Folha de $S$. Paulo, $2^{\circ}$ Caderno, São Paulo, 8 de maio de 1997.

102. Principes de Droit Civil français, $3^{\mathrm{a}}$ ed., Paris, Librairie A. Marescq Ainé, 1878, 1. XX, § 
não haveria problema, porque este arbítrio é uma característica da própria função jurisdicional. Além disso, pode este ser usado para o bem, de modo a se atribuir penas civis em proporção à gravidade do dano.

Minozzi, ${ }^{103}$ acompanhando e complementando Laurent, critica a objeção de Gabba, explicando que há situações em que um dano patrimonial também é de difícil resolução, ficando ao cargo do juiz a determinação do seu valor. Nãoobstante existirem tais casos, ninguém cogita de se lhes negarem a reparabilidade.

Isso ocorre todas as vezes em que existe uma análise subjetiva, tal como, v.g., na determinação do comportamento do diligens paterfamilias.

Assim, por exemplo, Tício abalroa o veículo de Semprônio, ao passar em um cruzamento. Se ambos afirmam que o semáforo estava fechado para o outro, como irá o magistrado verificar se houve negligência? Em princípio, por meio das circunstâncias do caso concreto, devidamente provadas nos autos. E se não houver como provar? Parte-se de presunções, caso estas existam. E se ainda persistir a dúvida? O juiz, com base na proibição do non liquet, deverá dar uma solução à controvérsia e, mesmo em se tratando de dano material, deverá sentenciar utilizandose de seu bom senso. Enfim, valerá o princípio da verdade formal, ${ }^{104}$ e sempre haverá o risco de abusos e arbitrariedades.

Desse modo, pode-se inferir que esse "inconveniente arbitrio" é inerente à própria função jurisdicional, que, segundo o critério do livre convencimento motivado, destinará ao juiz o papel de atribuidor do valor dos danos.

Ademais, o próprio ordenamento jurídico estabelece limites à atuação do juiz. Para isso, a Constituição Federal, em seu art. $5^{\circ}$ inciso LIV determina o respeito ao devido processo legal; em seu inciso LV se consagra a ampla defesa e o

395, pp. 415 e 416. A esse respeito, escreve o autor, in verbis: "Il est vrais qu'il est impossible d'évaluer en argent le dommage moral, le montan des dommages-intérêt sera donc toujours arbitraire" (...) "De ce que le juge ne peut pas accorder une réparations exacte on ne peut pas concluire qu'il ne doit pas accorder aucune réparation. L'arbitraire est ici dans la nature des choses et il peut tourner à bien parce qu'il permet au juge de prononcer des peines civiles sans limite aucune, donc en les proportionnant à la gravité du tort moral"

103. Op. cit. (nota 11), p. 76.

104. Explicam Ada Pellegrini Grinover, Cândido Rangel Dinamarco e Antônio Carlos de Araújo Cintra (Teoria Geral do Processo, $13^{a}$ ed., São Paulo, Malheiros Editores, 1997, p. 65) que verdade formal representa aquilo que resulta ser verdadeiro em face das provas carreadas dos autos, em oposição à verdade real que é de natureza material. Aquela vigora no processo civil e tem por fundamento o princípio dispositivo, ou seja, aquele pelo qual às partes caberá a produção de provas para que o juiz julgue com base nelas. 
contraditório. Em suma, existem determinados remédios previstos na Carta Magna que buscam impedir abusos, como, v.g., o mandado de segurança. O próprio duplo grau de jurisdição é uma garantia para o cidadão no que tange à proteção em face de arbitrariedade. Uma sentença de primeiro grau não-transita em julgado antes do término do prazo recursal.

Todavia, caso não se admitisse a reparação dos prejuízos morais em virtude de tal característica, ainda restaria ao magistrado, em razão do caso concreto, o dever de determinar qual seria o dano indenizável. E, mesmo assim, poderiam surgir situações limítrofes, de modo que continuaria a existir o tal "arbítrio"

Desse modo, entende Minozzi que o problema da indenização dos danos morais reside somente em seus limites. Apesar de ser perigoso alargar-lhe demais a esfera de reparação, pior seria deixá-lo fora da órbita do Direito. Enfim, trata-se de uma questão de custo-benefício. A dignidade da pessoa humana é um bem que deve ser tutelado pelo Direito, que constitui a primeira dentre as várias ciências ético-sociais. ${ }^{105}$

Porém, para se evitar abusos, poder-se-ia aceitar a idéia de o legislador atribuir critérios ou valores prefixados a determinados delitos dos quais podem originar danos morais, tal como ocorre no art. 53 da Lei de Imprensa (Lei n. 5.250, de 9 de fevereiro de 1967) ${ }^{106}$ e no art. 84 do Código de Telecomunicações (Lei n. 4.117, de 27 de agosto de $1962 \mathrm{com}$ as alterações do Decreto-Lei n. 236, de 28 de fevereiro de 1967). ${ }^{107}$

Entretanto, não seria admissível e isso deve ser frisado - a pretensão de uma imposição normativa que visasse a exaurir todas as hipóteses deste delito. A utilidade desta norma, seria apenas a orientação para o juiz determinar o quantum debeatur.

105. Op. cit. (nota 11), p. 78.

106. O art. 53 prescreve que: "No arbitramento da indenização em reparação do dano moral, o juiz terá em conta, notadamente: I a intensidade do sofrimento do ofendido, a gravidade, a natureza e a repercussão da ofensa e a posição social e política do ofendido; II - a intensidade do dolo ou o grau da culpa do responsável, sua situação econômica e sua condenação anterior em ação criminal ou cível fundada em abuso no exercício da liberdade de pensamento e informaçāo"

107. Cabe destacar que, segundo o art. $84, \S 1^{\circ}$ desta lei, "O montante da reparação terá o mínimo de 5 (cinco) e o máximo de 100 (cem) vezes o maior salário-mínimo vigente no País" 
IV 10. Impossibilidade de indenização do dano moral, de acordo com o critério da equivalência. $^{108}$

A presente crítica reside no fato de que, quando se cogita de indenizar um dano, deve-se ter em mente a busca pela reparação da lesão de acordo com o valor do bem avariado.

Para que isso ocorra, faz-se necessária a possibilidade de se traduzir o valor do prejuízo em termos pecuniários, para que, assim, seja possível calcular o montante a ser pago a título de reposição das perdas.

Eis, pois, o problema principal do dano moral: a impossibilidade de se encontrar uma unidade de medida deste dano e traduzi-la em uma dada quantidade de moeda.

Como se medir o quantum de dor que uma pessoa sofreu? E mesmo que surja uma tecnologia capaz de traduzir um sentimento em unidade de medida, como traçar uma equivalência entre a ofensa moral e dinheiro?

Em total contraposição a este raciocínio, Minozzi ${ }^{109}$ defende a possibilidade de uma equivalência entre o dano não-patrimonial e a indenização, sendo esta não menos próxima do que aquela aplicada às lesões materiais.

Isso porque a expressão "equivalência" não-significa igualdade. O dano sofrido será ressarcido por um critério de aproximação, pois utópica é a idéia de se conduzir o bem lesado ao estado que se encontrava anteriormente à violação de direito.

Desse modo, v.g., supondo-se um acidente de trânsito sem vítimas, cujo prejuízo seja apenas um carro batido. Mesmo este sendo consertado em uma oficina, nunca voltará à sua condição anterior, por mais caprichoso que seja o mecânico. Nunca mais será um automóvel novo e intacto. Além disso, o proprietário do veículo abalroado ficará privado de seu uso por alguns dias, o que lhe acarretará outros prejuízos, por vezes não-considerados pelo magistrado no cálculo do montante indenizatório.

Destarte, pagando o autor do delito a dívida decorrente do ato ilícito, haverá uma aproximação, de modo a se buscar tão-somente restabelecer ao ofendido situação similar à que existia antes do prejuízo, sem, porém, se ambicionar a

108. Gabba, op. cit. (nota 56), pp. 231 a 233.

109. Op. cit. (nota 11), p. 52. 
inatingível igualdade.

Nesse sentido, a impossibilidade de se estabelecer uma igualdade absoluta entre dano moral e indenização não-representa empecilho para o cálculo do montante a ser pago, levando-se em consideração a permissão atribuída pelo ordenamento jurídico ao juiz de, com base em critérios que produzam uma equivalência aproximativa, ${ }^{110}$ determinar o valor a ser pago pelo autor do prejuízo não-patrimonial.

Além disso, acrescenta o autor ${ }^{111}$ que será obtida a equivalência por meio da chamada "função satisfativa do dinheiro": entendida como a capacidade de o valor monetário produzir um sentimento agradável ao ofendido.

Assim, procurar-se-á, por meio do critério de aproximação, produzir um bem-estar à vítima do dano que compense o prejuízo moral decorrente da lesão. Isso fará a pessoa sentir-se satisfeita, sem, entretanto, pretender-se retornar àquela situação preexistente ao ato ilícito.

Nesse mesmo sentido, Pontes de Miranda ${ }^{1 / 2}$ entende que a tese da nãoreparabilidade de danos extrapatrimoniais em virtude da dificuldade de se calcular o valor não se funda. Isso porque, para a indenização, basta o dano ser tão-somente passível de avaliação mesmo que esta seja difícil - de modo a traçar-se uma proporção entre o dano e o valor a ser pago.

Não se cogita, pois, de exatidão. Apenas existe a necessidade de se reparar o dano moral em termos pecuniários, a fim de que o valor pago pelo ofensor possa, de algum modo, compensar a dor sofrida. Assim, v.g., com o dinheiro da indenização, improvisa-se uma viagem ao estrangeiro para que a mulher, que sofreu abalo com o assassínio do marido, se distraia. ${ }^{113}$

Afirma $^{114}$ que o argumento já vulgarizado, de que não se deveria reparar o dano moral, porque o ressarcimento não seria completo, não-convence. Entende não ser justo que nada se dê pelo fato de não haver exatidão aritmética.

110. Como, por exemplo, analogia em face dos preceitos da Lei de Imprensa (v. nota 106).

111. Id., ibid., nota 108.

112. Op. cit. (nota 10), t. 26 , p. 33 .

113. Id., ibid., nota 111 .

114. Op. cit. (nota 5), t. 53, p. 229. No mesmo sentido, cf. Martin-Achard, op. cit. (nota 65), p. 169. 
IV 11. O problema da não-existência de uma unidade de medida que permita comparar dor e dinheiro. ${ }^{115}$

Entretanto, ainda que se aceite a tese da equivalência aproximativa, o problema ainda persiste. Quem pretende medir uma totalidade sem uma unidade de medida não pode evitar que haja um resultado falso. Como então atingir essa aproximação sem que haja o risco de abuso?

Segundo Minozzi, ${ }^{116}$ no que tange às coisas in commercio realmente não há dificuldades nessa mensuração. Entretanto, um bem não deixará de ter valor somente porque lhe falta a medida e o preço unitário. Explica, pois, que o método de valoração é único. Todavia sua aplicação varia em virtude da natureza do objeto, da sua comercialidade e do gênero de valor que se considera, qual seja o de uso ou o de troca.

Dessa maneira, a cada dia se dá um valor, v.g., a obras de arte, invenções, sem que se cogite do preço do metro quadrado, peso, e outras formas de medida. Existiria, então, um critério de valorização relacionado à utilidade do bem.

Há diversas maneiras de se obter o valor de uma coisa, sendo uns mais próximos dos bens ordinariamente comercializados e outros em relação aos bens comumentes não-negociados.

Transpondo-se o raciocínio para o caso do dano moral, pode-se, em virtude da dificuldade de medi-lo e da não-existência de um preço de troca, através do chamado valor de uso de uma coisa ou utilidade subjetiva, chegar ao que a doutrina e a jurisprudência alemã denominará preço de afeição ("Schmerzensgeld").

Destarte, o critério de valoração de um bem será sempre relativo. Nãoexiste um preço absoluto. A própria moeda pode perder o seu poder de aquisição. $\mathrm{O}$ que determina o valor é o grau de atendimento às necessidades humanas. E isso acaba por ser traduzido pela lei da oferta e da procura. ${ }^{117}$

É claro que para certas coisas é possível determinar-se um preço unitário, em contraposição a uma unidade de medida. Mesmo assim, essa correlação preço/unidade decorrerá das leis de mercado. Porém, nem sempre isso será possível.

No próprio caso do dano não há que se falar em precisão matemática,

115. Gabba, op. cit. (nota 56), p. 233.

116. Op. cit. (nota 11), p. 57.

117. Minozzi, op. cit. (nota 11), p. 58. 
visto que cada vez que se determina o valor do bem lesado, há de se considerar a mudança do valor da própria moeda, ou da quotação do bem.

E no tocante às coisas corpóreas, existem situações em que não há como se determinar um preço por unidade, o que fará com que o seu valor seja determinado pela sua utilidade subjetiva. Ora, se não é possível determinar a relação preço por unidade, isso não implicará ausência de valor, como já visto. ${ }^{118}$

Desse modo, determina-se o valor do bem por meio de um critério qualitativo e, a partir desse raciocínio, estabelece-se a equivalência dano nãopatrimonial e indenização necessária.

Conclui Minozzi ${ }^{119}$ que, como o dano moral não se refere ao patrimônio do indivíduo lesado, não há como se partir de uma valoração objetiva. Demanda-se a vertente qualitativa de acordo com o critério da utilidade subjetiva. Isto porque em momento algum o Direito pede que só se indenize quando houver igualdade.

O autor, ${ }^{120}$ então, finalizará sua defesa, dizendo que "(...) non si tratta di rifare al danneggiato gli identici beni che há perduti, ma di far nascere in lui una nuova sorgente di felicita e di benessere, capace di alleviare le conseguenze del dolore, del male, che há ricevuto"

V. O dano moral no Direito brasileiro.

Diversas as hipóteses de previsão de indenização do dano moral no Direito brasileiro.

Inicialmente pode-se citar a própria Constituição Federal, de 1988, que, em seu art. $5^{\circ}$. estabelece:

$" V$ é assegurado o direito de resposta, proporcional ao agravo, além da indenização por dano material, moral ou à imagem;

$X$ são invioláveis a intimidade, a vida privada, a honra e a imagem das pessoas, assegurado o direito a indenização pelo dano material ou moral

118. Nesse sentido escreverá o autor (op. cit. (nota 11), p. 61), in verbis: "Poichè questi due dati [la traducibilità della cosa in unitá di misura e la traducibilitá di tale unità in unità de moneta] di fato non sempre sono possibili, la conseguenza è che certi cose si valutano com criteri soggetivi e non oggetivi, paragonando ciò̀ dolori e piaceri, soddisfazioni perduti e bisogni nati o risorti, con soddisfazioni e bisogni appagati"

119. Op. cit. (nota 11), p. 62.

120. Op. cit. (nota 11), p. 65. 
decorrente de sua violação;" [grifo nosso]

Deve-se destacar que a previsão constitucional da reparação do dano moral é considerada exemplificativa e não exaustiva. ${ }^{121}$ A Constituição Federal garante a reparação do dano moral qualquer que seja sua hipótese.

No Direito infraconstitucional há também diversos dispositivos em que se prevê tal indenização de forma clara. Exemplo destes é o já citado Código Brasileiro das Telecomunicações ${ }^{122}$ que, em seu art. 84 , estabelece critérios para a reparação do dano moral oriundo da calúnia, injúria ou difamação cometida por meio de radiodifusão:

"Art. 84. Na estimação do dano moral, o juiz terá em conta, notadamente, a posição social ou política do ofendido, a situação econômica do ofensor, a intensidade do ânimo de ofender, a gravidade e repercussão da ofensa.

$\S 1^{\circ} O$ montante da reparação terá o mínimo de 5 (cinco) e o máximo de 100 (cem) vezes o maior salário mínimo vigente no País.

$\S 2^{\circ} O$ valor da indenização será elevado ao dobro quando comprovada a reincidência do ofensor em ilícito contra a honra, seja por que meio for.

$\S 3^{\circ}$ A mesma agravação ocorrerá no caso de ser o ilícito contra a honra praticado no interesse de grupos econômicos ou visando a objetivos antinacionais." [grifo nosso]

No que toca ao Código Civil, juristas, tais como Silvio Rodrigues, ${ }^{123}$ defendiam uma previsão limitada de sua reparação, fundando-se nos arts. 1.543; 1.547, parágrafo único; 1.548 , inc. II; 1.549; 1.550; e 1.553 do Código Civil.

Outro dispositivo de grande importância para a atualidade é o Código de Defesa do Consumidor ${ }^{124}$ que, em seu art. $6^{\circ}$. incisos VI e VII estabelece o seguinte:

"Art. $6^{\circ}$ - São direitos básicos do consumidor:

VI a efetiva prevenção e reparação de danos patrimoniais e morais, individuais, coletivos e difusos;

121. A respeito, cf. Pereira, Caio Mário da Silva. Responsabilidade Civil, $2^{\text {a }}$ ed., $1^{\text {a }}$ tiragem, Rio de Janeiro, Forense, 1991, p. 65.

122. A respeito, $v$, nota 107.

123. Direito Civil - Responsabilidade Civil, São Paulo, Saraiva, 1975, v. IV, p. 206.

124. Lei n. 8.078 , de 8 de setembro de 1990. 
VII o acesso aos órgãos judiciários e administrativos, com vistas à prevenção ou reparação de danos patrimoniais e morais, individuais, coletivos ou difusos, assegurada a proteção jurídica, administrativa e técnica aos necessitados;" [grifo nosso]

O projeto do novo Código Civil, ${ }^{125}$ aprovado pelo Senado Federal, estabelece em seu art. 186:

"Art. 186. Aquele que, por ação ou omissão voluntária, negligência ou imprudência, violar direito e causar dano a outrem, ainda que exclusivamente moral, comete ato ilícito." [grifo nosso]

Desse modo, deve-se destacar que, após 1988, o problema relativo à possibilidade ou-não de se indenizar o dano moral tornou-se incontroverso em face ao Direito brasileiro.

Porém, para que se possa entender o caminho percorrido pela doutrina e jurisprudência no sentido de admiti-lo a ponto de elevá-lo à condição de mandamento constitucional, faz-se mister o estudo da evolução de sua apreciação no Direito pátrio.

V 1. Evolução da apreciação do dano moral no Direito brasileiro.

Ao tratar do dano moral, o Direito brasileiro passou por diversas mudanças nos últimos oitenta anos.

Inicialmente tal figura era totalmente negada por parte dos doutrinadores nacionais, tais como Lacerda de Almeida ${ }^{126}$ que não the aceitava sequer a existência, mesmo após a vigência do Código Civil de 1916.

Mais tarde, como explicado anteriormente, outros juristas, tais como Silvio Rodrigues, ${ }^{127}$ defendiam a previsão limitada de sua reparação no Código Civil.

Beviláqua ${ }^{128}$ e Aguiar Dias, ${ }^{129}$ apesar de também apresentarem uma interpretação limitativa, sobretudo no que toca ao homicídio, consideravam, de uma

125. Oliveira, Juarez de; Machado, Antônio Cláudio da Costa (organizadores). Novo Código Civil, São Paulo, Ed. Oliveira Mendes, 1998, p. 37.

126. A respeito do tema, v. notas 53 e 59.

127. Id., Ibid., nota 123.

128. Código Civil dos Estados Unidos do Brazil (Comentado), Rio de Janeiro, Livraria Francisco Alves, 1916, v. I, pp. 310 a 312.

129: O Dano Moral e sua Reparação, in Revista Forense, n. 144, Rio de Janeiro, 1952, p. 41. 
forma mais ampla, os arts. 76 e 159 como fundamentos da reparabilidade do dano moral no Direito Civil brasileiro. ${ }^{130}$

Outros doutrinadores, tais como Carvalho de Mendonça, ${ }^{131}$ bem como ministros do Supremo Tribunal Federal, como Pedro Lessa e Orozimbo Nonato, ${ }^{132}$ em posição minoritária, defendiam, desde a primeira metade do século, a tese da reparabilidade.

Entretanto, a doutrina apresentou-se resistente, somente vindo a mudar de posição entre os anos 50 e 60 , sendo o saudoso Pontes de Miranda ${ }^{133}$ um dos principais representantes dos que defendiam amplamente a tese de sua reparação.

A jurisprudência, por sua vez, foi a que mais resistiu. Atribui-se tal fato sobretudo em razão do positivismo exacerbado que vigorava na mentalidade dos tribunais do início até meados desse século, de modo que, em face da não-existência, até então, de texto expresso permitindo a indenização para determinados casos e, sobretudo, tendo em vista a dificuldade de avaliá-lo, preferiam afastá-lo a correr riscos. $^{134}$

Uma vez o estudo da evolução da jurisprudência apresentar-se de uma forma extremamente ampla, este será direcionado à verificação do dano moral em casos de homicídio e de lesão corporal, este, sobretudo, no que concerne ao dano estético. $^{135}$

V. 2. Responsabilidade civil por homicídio e lesões corporais físicas e psíquicas de acordo com o Código Civil brasileiro.

\section{2.1. Considerações gerais acerca do homicídio.}

No que tange ao homicídio, o Código apresenta o seguinte dispositivos:

130. Tal questão será aprofundada quando do estudo do dano moral no homicídio.

131. Op. cit. (nota 57).

132. A respeito destes últimos vide a análise jurisprudencial do dano moral.

133. A respeito veja estudo realizado anteriormente a respeito das teorias que negavam a reparação do dano, confrontadas com a opinião do autor.

134. A respeito cf. Azevedo, José Ozorio de Júnior. O Dano Moral e sua Avaliação, in Revista do Advogado, São Paulo, Associação dos Advogados de Sāo Paulo, n. 49, dezembro de 1996, pp. 8 e 9.

135. Para fins do presente estudo, considerar-se-á lesão corporal toda e qualquer lesão à integridade física da pessoa que não-acarrete morte. 
"Art. 1.537 - A indenização, no caso de homicídio, consiste:

I no pagamento das despesas com o tratamento da vítima, seu funeral e o luto da família;

II na prestação de alimentos às pessoas a quem o defunto os devia"

A partir de então, Pontes de Miranda traçará algumas considerações gerais:

No que concerne ao inciso I, entende o autor ${ }^{136}$ que a pretensão à indenização será daquele que efetivamente arcou com as despesas supramencionadas, estando obrigado o responsável pelo ocorrido.

Deve-se ressaltar que, regra geral, àquele que sofre o prejuízo cabe a pretensão indenizatória. Entretanto, como isto não é possível no caso do homicídio, visto a morte da vítima, o ordenamento jurídico atribui tal posição jurídica, primeiramente, àquele que despendeu recursos financeiros para o tratamento médico da vítima, funeral e sepultamento; em seguida, à família e àquele para o qual o defunto devia alimentos.

Destaca o autor que o elemento culpa não é essencial para que surja o dever de indenizar as despesas supramencionadas. O tratamento do homicídio previsto no Código Civil difere daquele constante no art. 121 do Código Penal visto que, independente de sua forma (doloso ou culposo), surge, no âmbito civil, uma mesma sanção, a saber, o dever de indenizar em virtude do simples nexo de causalidade entre a morte e o ato daquele que causou o dano. ${ }^{137}$

Em relação ao inciso II, explica que a pretensão e a ação dos que teriam direito a alimentos dirigem-se contra o mesmo responsável pelo fato.

Além disso, Pontes de Miranda ${ }^{138}$ entende que a expressão "família" não deve ser reduzida à "família legítima" A mulher que vive longo tempo com o de cujus também merece a prestação de alimentos, caso o falecido lhe a fornecesse (união estável).

Além disso, essa prestação de alimentos não-precisa ser decorrente de uma obrigação legal, como a do pai para com o filho. Pode haver uma situação de fato (criança que não seja parente e nem sequer adotada) que gere, para o

136. Op. cit. (nota 5), p. 280.

137. Op. cit. (nota 5), p. 282.

138. Op. cit. (nota 5), p. 283. 
prejudicado, a pretensão.

\section{2.2. Homicídio e dano moral.}

Adentrando na questão do dano moral, Aguiar Dias ${ }^{139}$ explica que no Direito Civil brasileiro não há como supor que se tenha querido afastar o dano moral de sua esfera de incidência.

O próprio art. 159 em momento algum afasta a sua consideração, visto não-explicitar a natureza do dano que engendraria o dever de indenizar.

Entretanto, segundo o mesmo autor, o Código de 1916 não-admite a cumulação do dano moral com o patrimonial de modo que, havendo elementos deste, não se indenizaria aquele.

Nesse sentido, interessantes comentários faz Beviláqua ${ }^{140}$ a respeito do art. 1.537 Explica que, no caso do homicídio, o dispositivo estabelece as bases de sua indenização, sem, entretanto, apreciar o dano moral, uma vez faltar elementos seguros para a sua apreciação. Conclui, nesse ponto, que os fatores "felicidade" e "bem-estar" seriam inapreciáveis, escapando à regulamentação traçada pela lei.

Washington de Barros Monteiro, ${ }^{141}$ a seu turno, entende que o Código peca pelo seu casuísmo ao elencar as diversas hipóteses de atos ilícitos que geram dever de indenizar, visto que tal implica restrições. Assim, segundo o eminente civilista, o art. 1.537 ao empregar a expressão "consiste" excluiria de sua esfera de incidência a indenização por lucros cessantes e o dano moral.

Entretanto, admitir-se o pagamento de verba de alimentos quando da morte do filho menor que não-exerce profissão lucrativa não seria uma forma de se indenizar o dano moral pela perda do ente querido?

Eis que tal problema encontrou lugar na jurisprudência que, em decisão citada por Caio Mário, ${ }^{142}$ não-obstante a lei falar em alimentos devidos, admitiu, em um caso do Tribunal de Alçada do Rio Grande do Sul (ADV, 1985, n. 24.564), tal indenização a título de reparação de dano moral e material.

Nesse sentido, entende o autor que a tendência na aceitação da tese da

139. Op. cit. (nota 2), p. 753.

140. Código Civil dos Estados Unidos do Brazil (Comentado), Rio de Janeiro, Livraria Francisco Alves, 1926, v. V, p. 320.

141. Curso de Direito Civil, $15^{\text {a }}$ ed., São Paulo, Saraiva, 1980, v. IV, p. 413.

142. A respeito do dilema vide Pereira, Caio Mário da Silva. Responsabilidade Civil, $2^{a}$ ed., Rio de Janeiro, Forense, 1990, p. 345. Vide também o estudo jurisprudencial infra. 
reparação do dano moral em casos de homicídio mostra-se evidenciada quando os tribunais passaram a atribuir indenização em casos de morte de filho menor que nãoconcorre para a mantença dos pais. ${ }^{143}$

\section{2.3. Considerações gerais acerca da lesão corporal.}

A respeito da lesão corporal, o Código Civil prescreve o seguinte:

"Art. 1.538 No caso de ferimento ou outra ofensa à saúde, o ofensor indenizará o ofendido das despesas do tratamento e dos lucros cessantes até o fim da convalescença, além de lhe pagar a importância da multa no grau médio da pena criminal correspondente.

$\S 1^{\circ} \quad$ Esta soma será duplicada, se do ferimento resultar aleijão ou deformidade.

$\S 2^{\circ}$ Se o ofendido, aleijado ou deformado, for mulher solteira ou viúva, ainda capaz de casar, a indenização consistirá em dotá-la, segundo as posses do ofensor, as circunstâncias do ofendido e a gravidade do defeito.

Art. 1.539 Se da ofensa resultar defeito pelo qual o ofendido não possa exercer o seu oficio ou profissão, ou se lhe diminua o valor do trabalho, a indenização, além das despesas do tratamento e lucros cessantes até o fim da convalescença, incluirá uma pensão correspondente à importância do trabalho, para que se inabilitou, ou da depreciação que ele sofreu."

A respeito da reparação do dano moral, Beviláqua ${ }^{144}$ observa que, no $\S$ $1^{\circ}$ do art. 1.538, existe uma combinação entre dano moral e material, enquanto que no $2^{\circ}$ somente se cogitaria do não-patrimonial.

Assim, o art. 1.538 caput trata de lesões transitórias que não chegam a acarretar um abalo moral. Há uma crítica a este dispositivo no que concerne ao pagamento da "importância da multa no grau médio da pena criminal correspondente" Verifica-se que o Direito Penal não-prevê tal penalidade. ${ }^{145}$

Pontes de Miranda dirá, então, que a multa prevista no artigo será

143. Op. cit. (nota 121), p. 69. Ainda a respeito cf. Superior Tribunal de Justiça, Recurso Extraordinário n. 85.123 - SP, $4^{\text {a }}$ T., j. 9.11.76, rel. min. Thompson Flores, in Revista Trimestral de Jurisprudência, s.l., v. 84, jun-1978, pp. 977 a 980.

144. Op. cit. (nota 140), p. 324.

145. O art. 129 do Código Penal determina a aplicação de penas privativas de liberdade, que variam conforme a gravidade do delito. Não existe a previsão de multa para esse delito. 
imposta por arbitramento, nos termos do art. 1.553 do Código Civil. ${ }^{146}$

$\mathrm{O} \S 1^{\circ}$ trata do dano estético, como forma de ofensa à integridade física da pessoa humana. Atenta, pois, contra um dos princípios fundamentais do direito de personalidade.

A duplicação da soma ali prevista trata da indenização pelos danos morais oriundos da deformidade, independente de qual seja o sexo do ofendido, exceto no caso da mulher, as solteiras ou viúvas que estarão amparadas pelo $\S 2^{\circ}$ do mesmo dispositivo legal.

Também estão fora as mulheres que exerçam profissão ou ofício fora do lar, pois que incidirá o art. 1.539.

No caso do homem, havendo diminuição da capacidade laborativa, aplicar-se-á o disposto no artigo supramencionado.

Ainda em relação ao $\S 1^{\circ}$ : a indenização será devida desde que ocorra dano estético, independendo de sua extensão. Isso porque o Direito Civil baseia-se no dano e não na culpa, de modo que, não-obstante o Código falar em lesão de grande monta, a reparação deverá ocorrer uma vez existindo o dano. ${ }^{147}$

Entretanto Teresa Ancona $^{148}$ entende que o dano indenizável será apenas o que tiver repercussão patrimonial. Somente por esse critério será possível, pela sistemática da lei, a determinação de um pretium doloris.

Nesse mesmo sentido, Caio Mário ${ }^{149}$ observa que, segundo o Tribunal de Justiça de São Paulo, o dano moral oriundo de dano estético somente seria indenizável quando produz, por si, dano econômico.

Tal conclusão merece ser refletida, pois que dano moral com repercussão patrimonial não-representa verdadeiro dano extrapatrimonial. Admitir a posição adotada pela eminente civilista e pela jurisprudência supramencionada poderia ser visto como uma espécie de refutação à própria consideração do dano moral uma vez que, na verdade, estaria sendo indenizado o dano patrimonial. ${ }^{150}$

146. Assim dispõe o artigo supramencionado: "Nos casos não previstos neste Capítulo, se fixará por arbitramento a indenização"

147. Magalhães, Teresa Ancona Lopes de. Dano Estético (Responsabilidade Civil), São Paulo, Ed. Revista dos Tribunais, 1980, pp. 97 a 109.

148. Op. cit. (nota 147), p. 99.

149. Op. cit. (nota 142), pp. 342 e 343.

150. E será a própria jurisprudência que resolverá tal controvérsia, no sentido de se aceitar a reparação, conforme será visto adiante. 
De qualquer modo, a evolução da apreciação do tema encontra-se respaldada nas decisões dos tribunais que, partindo da teoria civilista nacional e estrangeira, trouxeram grande contribuição ao pensamento jurídico brasileiro, o que culminou no art. $5^{\circ}$, incisos V e X da Constituição Federal, de 1988.

\section{3. Jurisprudência acerca do dano moral em casos de homicídio e lesão corporal.}

A apreciação do dano moral em casos de homicídio e lesão corporal no Direito Civil brasileiro passou por diversos estágios desde antes da entrada em vigor do Código de 1916.

A jurisprudência brasileira, em face das discussões doutrinárias que assolavam o meio jurídico no decorrer do século $\mathrm{XX}$, passou por uma verdadeira evolução no que tange à aceitação da reparação do dano moral em casos de homicídio e lesão corporal. ${ }^{151}$

a. Irreparabilidade (1915-1930)

Desde o início do século até os anos 20 a jurisprudência, baseada nos ensinamentos de Lacerda de Almeida, sequer admitia a existência de um dano nãopatrimonial.

Entretanto havia quem defendesse sua existência e reparação. O maior defensor desta figura dentro dos tribunais era o ministro do Supremo Tribunal Federal e professor catedrático da Faculdade de Direito de São Paulo, Pedro Lessa. $^{152}$

Este, em acórdão proferido em 26 de julho de 1915 que tratava de um caso de morte ocorrida em acidente ferroviário por volta de 1912 (período anterior à vigência do Código Civil), dizia o seguinte: "o que se protege, quando se ordena a indemnização do damno moral, são verdadeiros direitos, que nunca se puzeram em duvida" 153

No mesmo texto, o ilustre ministro explica que, em razão das dificuldades doutrinárias existentes na época, muitos países acabaram por adotar a

151. Para fins didáticos foram estabelecidos períodos em que as várias posições foram predominantes. Isso não significa que não houve decisões que contrariassem a tendência de cada época.

152. Supremo Tribunal Federal. Autos de embargo n. 1.723, j. 26.6.15, rel. min. Viveiros de Castro, in Revista Forense, Belo Horizonte, Imprensa Oficial do Estado de Minas, v. 24, 1915, pp. 473 a 480 .

153. Op. cit. (nota 151), p. 478. 
tese da não-reparabilidade, não-obstante a doutrina francesa defender a indenização deste dano.

Era, pois, a tese do dano moral não-aceita pela Jurisprudência brasileira, que, por vezes, apesar de cogitado pelo ministro Pedro Lessa, ${ }^{154}$ sequer discutia a sua possibilidade. ${ }^{155}$

Ao final de seu voto, ${ }^{156}$ faz severa crítica ao projeto de Código Civil, que daria origem ao de 1916: "Lembra o accordam que os nossos projectos do Codigo Civil têm sido unanimes em repellir a indemnização do damno moral, pelo que, dentro em breve, approvado o que ora discute o Congresso Nacional, nenhuma indemnização mais poderá decretar o poder judiciario brasileiro"

b. Irreparabilidade em função de sua não-previsão legal (1930-1967)

E este foi o fundamento do segundo período da não-reparação do dano moral no Direito brasileiro para os casos de homicídio e lesão corporal. A partir dos anos 30 até o final da década de 60 , aceita-se a existência de tal dano, porém o argumento para a sua não-reparação era que o Código Civil admitia em determinadas hipóteses expressamente consignadas no texto. ${ }^{157 \text { e } 158}$

154. Em voto proferido em 24 de dezembro de 1920, escrevia o eminente ministro, in verbis: "Não indemnizar o damno moral é deixar sem sanç̧ão um direito, ou uma série de direitos. A indemnização, por menor e mais insufficiente que seja, é a única sanç̧ão para os casos em que se perdem, ou se teem lesados a honra, a liberdade, a amizade, a affeição, e outros bens moraes, mais valiosos do que os economicos". Supremo Tribunal Federal. Apelação Cível n. 3.585, j. 24.12.20, rel. min. Pedro Lessa, in Revista Forense, Belo Horizonte, Imprensa Official do Estado de Minas Geraes, v. 37, 1921, p. 202.

155. A respeito, cf. Primeira Instância. Ação Ordinária, j. 4.7.29, juiz Laudo Ferreira de Camargo, in Revista dos Tribunais, São Paulo, Ed. Revista dos Tribunais, v. 74, maio-1930, pp. 375 a 377.

156. Op. cit. (nota 151), p. 479.

157. Assim, v.g., o art. 1.543 do Código Civil que estabelece: "Para se restituir o equivalente, quando não-exista a própria coisa (art. 1.541), estimar-se-á ela pelo seu preço ordinário e pelo de afeição, contanto que este não se avantaje àquele". [grifo nosso]

158. A respeito cf. Supremo Tribunal Federal. Recurso Extraordinário n. 12.039, j. 6.8.48, min. rel. Lafayette de Andrada, in Revista Forense, Rio de Janeiro, Ed. Forense, v. 127, jan-1950, p. 399. Beviláqua, citado pelo relator do acórdão, argumenta, in verbis, que: 'a) todo dano, seja patrimonial ou não, deve ser ressarcido, por quem o causou, salvante a escusa de fôrça maior, que, aliás, algumas vêzes não aproveita, por não precedida de culpa. É regra geral sujeita a exceção;' (...) " 'd) mas o dano moral, nem senpre é ressarcível, não sòmente por se não poder dar-lhe valor econômico, por se não poder apreciá-lo em dinheiro, como, ainda, porque essa insuficiência dos nossos recursos abre a porta a especulações desosnestas, acobertadas pelo manto nobilíssimo de sentimentos afetivos. Por isso, o Cód. Civil afastou as considerações de ordem exclusivamente moral, nos casos de morte e de lesões corpóreas não deformantes (art. 1.537 e 1.538)'" 
Porém havia opiniões isoladas no sentido da reparação total dessa hipótese de dano para os casos de homicídio e lesão corporal, tais como a do ministro do Supremo Tribunal Federal, Orozimbo Nonato. ${ }^{159}$

c. Reparabilidade (1967-1988)

A partir de 1967. novo rumo tomou a jurisprudência em matéria de danos morais. A tese ora adotada era a da reparação deste tipo de lesão, reconhecendo-o como espécie de dano previsto no art. 159 do Código Civil. ${ }^{160}$

Assim, um dos grande propagadores desta nova diretriz, o ministro Aliomar Baleeiro, ${ }^{161}$ em um caso de acidente de trânsito em cuja vítima fatal foi um menor impúbere, entendeu ser indenizável o dano moral baseando-se na idéia de que o art. 1.537 não exclui a indenização dos danos puramente morais (ao contrário do que aludem os autores supramencionados), ${ }^{162}$ na medida em que a mesma lei admite, para os casos não-previstos no capítulo referente à liquidação dos atos ilícitos, a fixação da indenização por arbitramento (art. 1.553).

Desse modo, ao considerar a situação dos pais do menor falecido, conclui que: "se o responsável pelo homicídio lhes frusta a expectativa futura e a satisfação atual, deve a reparação, ainda que seja a indenização de tudo quanto despenderam para um fim lícito malogrado pelo dolo ou culpa do ofensor" 163

E qual o critério para esse "arbitramento"? Deve-se levar em conta sobretudo quanto foi despendido para a criação e a educação do menor, mais honorários e juros compostos desde a data do acidente.

A respeito da lesão corporal, especificamente no caso do dano estético, surgiram algumas questões interessantes, sobretudo no que toca à situação da mulher.

A respeito deste tema, pode-se citar o caso de uma mulher de dezenove anos, solteira, estudante de Filosofia que, ao passar em determinado

159. A respeito cf. Supremo Tribunal Federal. Apelação n. 7.526, j. 3.11.42, rel. min. Orozimbo Nonato, in Revista Forense, Rio de Janeiro, Ed. Forense, v. 94, abr-1943, pp. 477 a 481.

160. A respeito, cf. Supremo Tribunal Federal. Recurso Extraordinário n. 71.128 GB $2^{\mathbf{a}}$ T., j. 8.5.72, rel. min. Antônio Neder, in Revista Trimestral de Jurisprudência, s.1., v. 62, out-1972, p. 104.

161. Supremo Tribunal Federal. Recurso Extraordinário n. 59.940 - SP - $2^{\mathrm{a}}$ T., j. 26.4.66, min. rel. Aliomar Baleeiro, in Revista Trimestral de Jurisprudência, s.1., v. 39, jan-1967, pp. 38 a 44.

162. A respeito $\mathrm{cf}$. as considerações gerais acerca do homicídio e da lesão corporal estudadas no presente trabalho.

163. Op. cit. (nota 161), p. 40. 
logradouro, foi atingida por grandes pedaços de argamassa que se desprenderam de um edifício, o que implicou a amputação de sua perna direita, na altura do tornozelo. $^{164}$

Teresa Ancona ${ }^{165}$ entende ser indenizável o dano moral nos termos do $\S 1^{\circ}$, do art. 1.538, uma vez a exegese da expressão "soma a ser duplicada" referirse ao valor correspondente à indenização do dano não-patrimonial.

Nesse sentido complementa o ministro Thompson Flores ${ }^{166}$ que: "embora o Código Penal não cogite de multa, para os crimes de ofensa física, $e$, justamente, por tal fato, cabivel a reparação, na esfera civil, a qual, de resto, independe da criminal"

Ademais, a lei prevê, no $\S 2^{\circ}$ do art. supramencionado, a situação da mulher solteira e em idade de casar que, pelo dano estético, tem esta possibilidade diminuída. Neste caso, cabe indenização a ser paga por meio de um dote.

Porém ela trabalhava e estudava Filosofia. Conforme explica o acórdão suprareferido, ela, junto com o irmão, era arrimo de família e o acidente acarretou-lhe, além dos danos patrimoniais, imensa angústia diante da hipótese desta não mais poder exercer sua profissão. Nesse sentido, o caso também se enquadraria na previsão do art. 1.539 .

Diante da coexistência de diversas hipóteses de incidência qual deve prevalecer?

Segundo o acórdão, todos os dispositivos poderiam ser aplicados, nãoobstante a decisão recorrida ter considerado apenas o art. 1.539. Apesar disso, preferiu o Tribunal reconhecer-lhe direito à indenização pelos danos morais sofridos, com base no que havia sido estipulado em decisão de instância anterior, prevalecendo a aplicação do art. 1.539 .

Porém, a conclusão relativa ao problema de se determinar o quantum a ser pago e a que título (dote ou diminuição da capacidade laborativa) é a de que, em face a dificuldade de avaliação, a quantia deve ser estabelecida com base no princípio estabelecido no art. $1.543 .^{167}$

164. Supremo Tribunal Federal. Recurso Extraordinário n. 69.754 - SP - $2^{\mathrm{a}}$ T., j. 11.5.71, rel. min. Thompson Flores, in Revista Trimestral de Jurisprudência, s.l., v. 57, jan-1971, p. 787 a 790.

165. Op. cit. (nota 147), p. 99.

166. Op. cit. (nota 164), p. 788.

167. O artigo, ao falar em se pagar um preço de afeição, sem que o indenizado se avantaje daquele, estabelece o princípio pelo qual o dano moral não deve ser fonte de enriquecimento sem 
Desse modo, abandonando o exacerbado positivismo do início do século, os tribunais serão marcados pelo aumento do arbítrio acerca do dano moral, nas hipóteses em que a lei não-fixa desde logo os critérios pelos quais a decisão deve guiar-se. $^{168}$

d. Ampla reparabilidade (após 1988)

Com o advento da Constituição Federal de 1988, nova guinada tomou a jurisprudência brasileira.

Agora, a reparabilidade do dano moral é ponto pacífico, restando dúvidas acerca de como se determinar o quantum a ser arbitrado pelo juiz.

Nesse sentido, diversas soluções foram sendo apresentadas pela jurisprudência.

Um exemplo, é o caso de um rapaz que foi assassinado por um policial na Rodovia Rio-Santos, ao parar no acostamento após determinação da autoridade. Em ação ordinária ${ }^{169}$ intentada pelos pais da vítima entendeu o juiz pela procedência no tocante à responsabilidade civil do Estado, tendo em vista o nexo de causalidade existente entre a conduta do policial e o dano (morte da vítima).

Para fins de arbitrar o valor da indenização a título de danos morais, considerou-se desde a teoria do risco administrativo até questões de ordem fática de modo a, in verbis, "brecar com a tendência conservacionista e o sentimento de impunidade que pairam neste país" (fls. 991).

Ainda no tocante a critérios de determinação do quantum, o eminente magistrado, citando João Casillo, ${ }^{170}$ apresenta alguns retirados da doutrina, a saber, a idade da vítima, a incapacidade relativa ou permanente que sofreu, a privação de outras satisfações pessoais, a importância da lesão ou da dor sofrida, assim como sua duração e seqüelas, o sexo da vítima, o caráter permanente ou-não do menoscabo que ocasiona o sofrimento, o grau de parentesco com a vítima e a valorização da sensibilidade do lesado e de seus familiares.

Com base nos critérios supramencionados, o juiz condenou o Estado a

causa.

168. A respeito cf. Casillo, João. Dano Moral. Indenização - Critério para fixação, in Revista dos Tribunais, São Paulo, Ed. Revista dos Tribunais, v. 634, ago-1988, p. 235 a 236.

169. Primeira Instância. $7^{a}$ Vara da Fazenda Pública SP, Ação Ordinária de Indenização $n$. 452/94, j. 9.6.95, juiz Danilo Panizza Filho, São Paulo, jun-95.

170. Dano à Pessoa e sua Indenização. Apud op. cit. (nota 168), fls. 982 e 983. 
pagar a quantia de $\mathrm{R} \$ 800$ mil aos pais da vítima, a título de ressarcimento de danos morais.

Entretanto, tal não é o posicionamento da maior parte da jurisprudência. Os julgados dos tribunais tenderam a uma posição mais comedida e, assim, por meio de critérios diversos atribuem indenizações que dificilmente atingem o valor suprareferido.

Posto isto, antes do estudo dos critérios mais utilizados na Segunda Instância, fazem-se mister algumas ressalvas.

A primeira grande dúvida apresentada refere-se à questão da possibilidade de se acumular dano material com o moral. Tal questão foi respondida por meio da Súmula 37 do Superior Tribunal de Justiça que prescreve: "São cumuláveis as indenizações por dano material e dano moral, oriundos do mesmo fato"

Pode um ato ilícito culposo ocasionar um dano moral? Como se ofender a moral culposamente? Tal resposta é dada pela jurisprudência que afirma existir nesses casos a responsabilidade pelo simples fato da violação. Havendo o nexo de causalidade entre ação ou omissão e a lesão, surge o dever de reparar, independente a prova da ocorrência de prejuízos. ${ }^{171}$

No tocante à determinação do valor, vigora a tese do arbitramento com base no art. 1.553 .

Entretanto, curiosa é a determinação, por parte de diversas decisões, de se aplicar dispositivos legais que não se relacionam diretamente com o homicídio e lesão corporal.

Nesse sentido, interessante é a ementa de acórdão proferido no $1^{\circ}$ Tribunal de Alçada Civil que estabelece a aplicação do Código Brasileiro de Telecomunicações (que trata de injúria, calúnia e difamação) para um caso de lesão corporal. $^{172}$

171. A respeito cf. Superior Tribunal de Justiça. Recurso Especial n. 23.575 - DF, $4^{\text {a }}$ T., j. 9.6.97, rel. min. César Asfor Rocha, in Revista dos Tribunais, São Paulo, v. 746, dez-1997, p. 183 a 187.

172. Primeiro Tribunal de Alçada Civil. Apelação n. 698.188-0 $2^{\mathrm{a}}$ C. j. 15.01.97, rel. juiz Alberto Tedesco, in Revista dos Tribunais, São Paulo, Ed. Revista dos Tribunais, v. 740, jun-1997, pp. 308 a 311 . Prescreve a ementa do acórdão: "A lesão à integridade física proveniente de acidente de trânsito, além de acarretar a indenização por danos pessoais e patrimoniais, possibilita também a reparação por danos morais. Na ausência de parâmetros, para que se possa calcular o valor do dano moral a ser indenizado, tem-se utilizado o preceito estabelecido pela Lei $n .4 .117 / 62$ Código Brasileiro de Telecomunicações, que adota o critério de que o montante da reparação não será inferior a cinco, nem superior a cem vezes o maior salário mínimo vigente no País, variando de 
Também há julgados ${ }^{173}$ que fundamentam a indenização com base no art. 21 do Decreto n. 2.681 de 1912, que prescreve:

"No caso de lesão corpórea ou deformidade à vista da natureza mesma e outras circunstâncias, especialmente a invalidez para o trabalho ou profissão habitual, além das despesas com o tratamento e os lucros cessantes, deverá ser pelo Juiz arbitrada uma indenização especial"

De qualquer modo, tendo em vista que, em verdade, não existe previsão expressa de critérios para se determinar o quantum, a jurisprudência acaba por atribuir valores os mais diversos, de acordo com as circunstâncias do caso concreto.

Nesse sentido, fala-se em cem salários mínimos, de acordo com o Código de Telecomunicações; valor reduzido de 510 para 250 salários; ${ }^{174}$ cinqüenta salários mínimos; ${ }^{175}$ em outro julgado o valor é aumentado de duzentos para quatrocentos salários mínimos; ${ }^{176}$ diz-se da fixação do quantum "no valor correspondente à importância percebida pelo empregado à época do evento dada a irreversibilidade do quadro e a ausência de aptidão deste para exercer outra atividade laboral"; ${ }^{177}$ etc.

VI. Breve reflexão a respeito da natureza do dano moral: critérios adotados para a determinação do quantum.

Como se pode notar, ainda hoje não-existe uma uniformidade no que se refere aos critérios de determinação do quantum debeatur a título de dano moral.

O que se reconhece, entretanto, é a sua reparabilidade. A Constituição Federal adota esta tese com toda amplitude, o que implica a não-admissão de qualquer condicionamento em relação à sua atribuição.

acordo com a natureza do dano e as condições sociais e econômicas do ofendido e do ofensor"

173. Superior Tribunal de Justiça. Recurso Especial n. 65.393 RJ, 4a T., j. 30.10.95, rel. min. Ruy Rosado de Aguiar, in Revista dos Tribunais, v. 731, set-1996, p. 226 a 229.

174. Tribunal de Justiça de Rondônia. Apelação n. 3.454/94 RO, j. 7.3.95, rel. des. Eurico Montenegro Júnior, in Revista dos Tribunais, v. 724, fev-1996, p. 425 a 428.

175. Primeiro Tribunal de Alçada Civil. Apelação n. 562.964-5, j. 29.7.94, rel. juiz Carlos Roberto Gonçalves, São Paulo, jul-94.

176. Tribunal de Alçada do Rio Grande do Sul. Ap. $195.039 .094 \quad 6^{\mathbf{a}} \mathrm{C}$ j. 20.4 .95 rel. juiz Armínio Abreu Lima da Rosa, in Revista dos Tribunais, v. 723, jan-96, pp. 467 a 474.

177. Tribunal de Alçada do Paraná. Ap. 64.605-9 $\quad 3^{\text {a }}$ C. j. 12.4 .95 rel. juiz Ivan Bortoleto, in Revista dos Tribunais, v. 723, jan-96, pp. 461 a 467. 
Enfim, a analogia é o principal recurso adotado pelos tribunais, de modo que, em última análise, o arbitramento da indenização acaba por pautar-se nos termos do art. 1.553 do Código Civil.

Fato é que o Código Brasileiro de Telecomunicações vem sendo utilizado para casos de homicídio e lesão corporal, não-obstante estabelecer diretrizes para os crimes de injúria, calúnia e difamação cometidos pelos órgãos da imprensa radiodifusora.

Assim, limitando o quantum até o teto de cem salários, os tribunais, prudentemente, evitam situações abusivas. Afinal, dano moral deve ser encarado como uma reparação e não como fonte de renda. É óbvio que não-existe a obrigação legal de as decisões seguirem o texto supramencionado, mas já é um ponto de partida para que o legislador possa refletir sobre a questão e criar disposições específicas para casos mais correntes, como, v.g., o homicídio e a lesão corporal.

Ainda no tocante à legislação utilizada, faz-se mister uma reflexão a respeito dos critérios elencados pelo art. 84 .

Segundo o dispositivo, já estudado nesse trabalho, a indenização dos danos morais deve ter por base a posição social ou política do ofendido, a situação econômica do ofensor, a intensidade do ânimo de ofender e a gravidade e repercussão da ofensa.

Ao se cogitar da "situação econômica do ofensor" para a quantificação do quantum, o que é que se busca? Sabe-se que, se o ofensor é uma empresa de grande porte, a tendência é atribuir-se uma indenização maior. Mas isto não seria uma forma de punição? Representa o dano moral uma resposta do Direito a título de vingança?

Segundo Minozzi, Aguiar Dias e Fischer, conforme estudado anteriormente, a reparação do dano moral não-possui um aspecto punitivo. Aliás, não-obstante a lei brasileira estabelecer a independência da responsabilidade civil em face da penal (art. 1.525 do Código Civil), uma punição dupla poderia representar um bis in idem.

Ademais, se o dano moral fosse uma forma de pena privada, aos moldes do Direito Romano, seria necessário a imposição de critérios objetivos e com valores predeterminados. Isto porque, no Brasil, vigora o princípio do nulla poena sine lege. Não caberia analogia em matéria de pena, ainda que esta fosse privada.

É verdade que o Direito Civil prevê punições. Existem figuras tais como as arras punitivas (art. 1.095), a cláusula penal (art. 916), e mesmo o dever de 
restituir em dobro o valor cobrado antes do vencimento (art. 1.531). Mas todas estas podem ser objetivamente reconhecidas e determinadas, sem que se verifique a necessidade do uso de analogia ou qualquer outra divagação de caráter subjetivo.

Nesse sentido, o fato de os tribunais adotarem, por analogia, o Código Brasileiro de Telecomunicações poderia ser encarado como uma boa solução no sentido de limitar os anseios inquisitivos que possam surgir quando se busca reparar o dano moral.

Como este deve ser indenizado amplamente, nos termos no art. $5^{\circ}$ incisos $\mathrm{V}$ e $\mathrm{X}$ da Constituição Federal, deve ser enfatizado o seu aspecto compensatório, deixando a vertente punitiva num segundo ou até terceiro plano, sob pena de se criar a chamada "indústria do dano moral"

Justiça se faz pelo respeito às leis, pela eqüidade e, sobretudo, pelo bom senso. Afinal, como bem ressalta o grande jurista romano Celso, ${ }^{178}$ ius est ars bonum et aequum. E isso deve ser considerado ao se tratar do dano moral.

VII. Outras formas de reparação.

Outra questão de grande relevância, quando se trata da reparação do dano moral, é a possibilidade de se forjar outras formas de reparação, que não a pecuniária.

Nesse sentido, há aqueles que defendem a possibilidade de se impor ao ofensor uma obrigação de fazer em face do ofendido, não-obstante a condenação ao pagamento de um quantum aparentar ser uma forma mais "natural" de reparação. ${ }^{179}$

Assim, conforme explica Carlos Alberto Bittar, ${ }^{180}$ os objetivos visados direcionam-se também ao ofensor. Como, por exemplo, se este não possui bens, o que frustraria a pretensão do lesado, poder-se-ia compeli-lo a obrigações de fazer, ou não-fazer.

Nesse sentido, admite-se algumas situações em que se poderia pensar nessa solução.

Poderia ser o ofensor obrigado a, v.g., desmentir uma difamação,

178. A respeito, cf. Ulp. 1 inst. D. 1, 1, 1.

179. A respeito, cf. Yarshell, Luis Flávio. Dano Moral: Tutela Preventiva (ou Inibitória), Sancionatória e Específica, in Revista do Advogado, São Paulo, Associação dos Advogados de São Paulo, n. 49, dezembro de 1996, p. 62.

180. Reparał̧ão Civil por Danos Morais, São Paulo, Gráfica Editora Ltda., 1992, pp. 215 a 219. 
publicando a verdade na primeira página de um jornal de grande circulação; ou poderia ser proibido, durante determinado prazo, de freqüentar certos lugares. Além disso, poder-se-ia restringir o exercício de algum direito, e assim por diante.

Ainda no que toca esse tema, entende a doutrina ser possível a cumulação a título de reparação de danos morais, de uma obrigação de dar, fazer e não-fazer em uma mesma sentença, de modo que, em última análise, tal sanção, além de acarretar o ressarcimento do prejuízo moral, representaria efetivo desestímulo à sua prática. $^{181}$

Entretanto esta teoria merece algumas ressalvas. O segundo escopo, a saber, o desestímulo à prática do ilícito, não-obstante o caráter preventivo, apresenta uma vertente punitiva. E isto não é negado pela doutrina. ${ }^{182}$

É certo que o ordenamento jurídico deve buscar o melhor convívio entre as pessoas, aplicando, quando necessário, sanções punitivas. Entretanto, em se tratando de danos morais, tal meta torna-se arriscada na medida em que sua previsão legal é extremamente vaga. Como visto, os tribunais vêm aplicando o art. 1.553 do Código de modo a arbitrar um valor de acordo com cada caso.

Ademais, segundo o art. $5^{\circ}$, inciso XXXIX, não há pena (seja esta de Direito Civil ou Penal) sem prévia cominação legal. E este preceito deve ser respeitado, pois, caso contrário, haverá abusos, talvez muito mais graves do que uma quantificação pecuniária excessiva.

Em razão da falta de clareza por parte do legislador, junto ao fato de que é impossível se prever todas as hipóteses de dano moral, soa perigoso pensar em reparação não-pecuniária.

Há muito tempo o Direito Romano, por meio da Lex Poetelia Papiria, procurou abolir a responsabilidade corporal do Direito das Obrigações e isto não pode ser esquecido, mesmo em se tratando de um ato ilícito. Uma obrigação de fazer ou não-fazer desmesurada pode equiparar-se a uma situação parecida com o período da vindicta, antes mesmo da Lei de Talião. ${ }^{183}$

181. Op. cit. (nota 180), p. 217.

182. A respeito explica Bittar, id., ibid., nota 181: "Com efeito, conscientizou-se a doutrina, de um lado, de que é necessário que o agente sinta as conseqüencias da resposta do ordenamento jurídico, para que o sistema tenha eficácia, $e$, de outro, mister se faz dotar-se a reparação cabível de expressão que sirva de exemplo para a sociedade, tudo para a realização efetiva de sua função inibidora" [grifo nosso]

183. A respeito desse tema, v. a origem histórica do sistema de delitos privados, estudado anteriormente neste trabalho. 
Desse modo, a vertente punitiva do dano moral deve ser prevista de forma clara na lei. Caso isto não ocorra, deve-se estudar com calma a chamada "função inibidora" 184

Finalmente, talvez seja por essa razão que os tribunais vêm adotando a reparação pecuniária.

VIII. Considerações Finais

Como se pode notar, diversas questões continuam em aberto no tocante à reparação do dano moral. Não-obstante, de acordo com a Constituição Federal, este deve ser amplamente indenizado.

Mas como? Quais os critérios? Como determinar o quantum? Dano moral é compensatório ou punitivo?

No tocante ao homicídio e à lesão corporal, a Jurisprudência brasileira apresenta diversas soluções, sendo que a mais interessante é a adoção do Código Brasileiro de Telecomunicações como parâmetro de fixação do valor da indenização.

Certo é que a lei não é clara no tocante a essa matéria, uma vez conferir aos tribunais preceitos extremamente vagos, que dão margem, inclusive, a abusos.

Diante dessa característica negativa, uma possível solução, para que se evite abusos, seria a desconsideração do caráter punitivo do dano moral, enquanto não-houvesse uma previsão legislativa objetiva nesse sentido.

E para defender a presente tese, vale citar a opinião do ilustre civilista Caio Mário ${ }^{185}$ que afirma, in verbis: "O problema de sua reparação deve ser posto em termos de que a reparação do dano moral, a par do caráter punitivo imposto ao agente, tem de assumir um sentido compensatório. (...) "Somente assumindo uma concepção desta ordem é que se compreenderá que o direito positivo estabelece o princípio da reparação do dano moral"

Assim, tendo em vista a inexistência de critérios legais objetivos para que se puna aquele que ofende alguém moralmente, deve prevalecer o caráter compensatório do dano moral, por meio da imposição de indenização pecuniária.

Só assim não haverá problema em se permitir ao aplicador do direito arbitrar o quantum nos termos do art. 1.553 do Código Civil, visto que não se

184. Cf. nota 181 .

185. Op. cit. (nota 121), p. 69. 
buscará vingar o ofendido, mas sim proporcionar-lhe um bem-estar que reduza a dor sentida. A moderação será conseqüência da natureza compensatória da indenização.

Desse modo, a Constituição Federal será respeitada e chegar-se-á, concretamente, a uma ampla reparação dos danos morais.

São Paulo, dezembro de 1998.

IX. Bibliografia

IX. 1. Livros e artigos

AITH, Marcio. "Maranhão tem Indústria de Indenização", in Folha de S. Paulo, $2^{\circ}$ Caderno, São Paulo, 8 de maio de 1997.

ALMEIDA, Lacerda de. Obrigações. $2^{a}$ ed., São Paulo, Typographia Revista dos Tribunais, 1916.

AUBRY e RAU. Cours de Droit Civil Français, Paris, Imprimerie et Librairie Générale de Jurisprudence Marchal et Billard, 1920, t. VI.

AZEVEDO, José Ozorio de Júnior. O Dano Moral e sua Avaliação, in Revista do Advogado, São Paulo, Associação dos Advogados de São Paulo, n. 49, dezembro de 1996, pp. 7 a 14.

BEVILÁQUA, Clóvis. Código Civil dos Estados Unidos do Brazil (Comentado), Rio de Janeiro, Livraria Francisco Alves, 1916, v. I.

Código Civil dos Estados Unidos do Brazil (Comentado), Rio de Janeiro, Livraria Francisco Alves, 1926, v. V.

BITTAR, Carlos Alberto. Reparação Civil por Danos Morais, São Paulo, Gráfica Editora Ltda., 1992.

BOVE, Lucio. Danno (Diritto Romano), in Novissimo Digesto Italiano. $3^{\mathrm{a}}$ ed., Turim, Unione Tipografico Editrice Torinese, 1957, t. V

CAPITANT e COLIN. Cours Elémentaire de Droit Civil Français. 2a ed., Paris, Librairie Dalloz, 1953, t. III.

CARBONIER, Jean. Derecho Civil Situaciones Extracontratuales y Dinámica de las Obligaciones. Trad. Manuel Maria Zorrilla Ruiz. Barcelona, Bosch Casa Editorial, 1971, t. II, v. III. 
CASILlO, João. Dano Moral. Indenização - Critério para fixação, in Revista dos Tribunais, São Paulo, Ed. Revista dos Tribunais, v. 634, ago-1988, pp. 235 a 236.

CHAMOUN, Erbert. Instituições de Direito Romano. $5^{\mathrm{a}}$ ed., Rio de Janeiro, Forense, 1968.

CHIRONI, Giampietro P La Colpa nel Dirito Civile Odierno (Colpa extracontrattuale), $2^{\text {a }}$ ed., Turim, Fratello Bocca Editori, 1906, v. II.

CORREIA e SCIASCIA. Manual de Direito Romano. $2^{\mathrm{a}}$ ed., São Paulo, Saraiva, 1953, v. I.

DIAS, José de Aguiar. O Dano Moral e sua Reparação, in Revista Forense, n. 144, Rio de Janeiro, 1952, pp. 41 a 45. Responsabilidade Civil. $10^{\mathrm{a}}$ ed., Rio de Janeiro, Forense, 1997, v. II.

DINIZ, Maria Helena. Curso de Direito Civil Brasileiro. $2^{\mathrm{a}}$ ed., São Paulo, Saraiva, 1986, v. 7.

FISCHER, Hans Albrecht. A reparação dos danos no Direito Civil, São Paulo, Saraiva, 1938.

FRANÇA, Limongi. Reparação do Dano Moral, in Revista dos Tribunais, São Paulo, Revista dos Tribunais, v. 631, maio-1988, pp. 29 a 37.

GABBA, Carlo Francesco. Risarcibilità dei danni morali, in Questioni di Diritto Civile Diritto Ereditario e Diritto delle Obligazioni. $2^{\mathrm{a}}$ ed., Torino, Fratelli Bocca Editore, 1911, v. II.

GARCIA, Hamilcar de. Dicionário Contemporâneo da Língua Portuguesa. $3^{\mathbf{a}}$ ed., Rio de Janeiro, Ed. Delta, 1980.

GIRARD, Paul Frédéric. Manuel Elementaire de Droit Roman. $4^{\mathrm{a}}$ ed., Paris, Librairie Nouvelle de Droit et de Jurisprudence, 1906.

GRINOVER, Ada Pellegrini; DINAMARCO, Cândido Rangel; e CINTRA, Antônio Carlos de Araújo. Teoria Geral do Processo. 13 ${ }^{a}$ ed., São Paulo, Malheiros Editores, 1997.

JOURDAIN, Patrick. Les Principes de la Responsabilité Civile. $3^{\mathrm{a}}$ ed., Paris, Dalloz, 1996.

LAURENT, F Principes de Droit Civil français. $3^{\mathbf{a}}$ ed., Paris, Librairie A. Marescq Ainé, 1878, t. XX, § 395.

MAGALHÃES, Teresa Ancona Lopez de. Dano Estético (Responsabilidade Civil), São Paulo, Ed. Revista dos Tribunais, 1980. 
MARKY, Thomas. Curso Elementar de Direito Romano. $8^{\mathrm{a}}$ ed., São Paulo, Saraiva, 1995.

MARTIN-ACHARD. De la Réparation Pécuniaire du Tort Moral, Genebra, Livraria Künding, 1908.

MAYNZ, Charles. Cours de Droit Romain. $5^{\mathbf{a}}$ ed., Paris, A. Durant \& Pedone Lauriel, 1891.

MEIRA, Silvio. Instituições de Direito Romano. $3^{\mathrm{a}}$ ed., São Paulo, Max Limonad, 1968.

MELlo DA SILVA, Wilson. O Dano Moral e sua Reparação, Rio de Janeiro, Forense, 1955.

MENDONÇA, Manuel Ignacio Carvalho de. Doutrina e Prática das Obrigações ou Tratado dos Direitos de Crédito. $3^{\mathrm{a}}$ ed., Rio de Janeiro, Livraria Editora Freitas Bastos, 1938, v. II.

MINOZZI, Alfredo. Studio Sul Danno Non Patrimoniale (Danno Morale). $2^{\mathrm{a}}$ ed., Milão, Società Editrice Libraria, 1909.

MONTEIRO, Washington de Barros. Curso de Direito Civil. $15^{\mathrm{a}}$ ed., São Paulo, Saraiva, 1980, v. IV

MOREIRA ALVES, José Carlos. Direito Romano. 10 ed., revista e acrescentada, Rio de Janeiro, Forense, 1995, v. I.

Direito Romano. $3^{\mathbf{a}}$ ed., Rio de Janeiro, Forense, 1980, v. II.

OLIVEIRA, Juarez de; MACHADO, Antônio Cláudio da Costa (organizadores). Novo Código Civil, São Paulo, Ed. Oliveira Mendes, 1998.

PEREIRA, Caio Mário da Silva. Responsabilidade Civil. $2^{\text {a }}$ ed., Rio de Janeiro, Forense, 1990. Responsabilidade Civil. $2^{\mathrm{a}}$ ed., $1^{\mathrm{a}}$ tir., Rio de Janeiro, Forense, 1991.

PLESCIA, Joseph. The Development of "Iniuria" In Labeo Rasegna di Diritto Romano, Nápoles, Jovene, 1977, v. 23-3.

PONTES DE MIRANDA, Francisco. Tratado de Direito Privado Parte Especial. $3^{\mathrm{a}}$ ed. (reimpressão), Rio de Janeiro, Borsoi, 1971, t. 26.

Tratado de Direito Privado Direito das Obrigações, Rio de Janeiro, Borsoi, 1966, t. 53.

RODRIGUES, Silvio. Direito Civil Responsabilidade Civil, São Paulo, Saraiva, 1975 , v. IV 
SALAZAR, Alcino de Paula. Reparação do Dano Moral, Rio de Janeiro, Borsoi, 1943.

SERANGELI, Sandro. C. 7, 16, 31 e Le Azioni Contro Il Litigante Temerario. In Bulletino Dell'Istituto di Diritto Romano "Vittorio Scialoja", Milão, Dott. A. Giuffrè Editore Milano, terceira série, 1968, v. X (v. LXXI da coleção inteira).

SIMONE, Enrico de. D. 47.10.1.6-7. In Labeo - Rassegna di Diritto Romano, Nápoles, Jovene, 1966, v. 12-3.

TUHR, Andreas Von. Tratado de las Obligaciones. Trad. do alemão por W. Roces. $1^{\text {a }}$ ed., Madri, Editorial Reus S/A, 1934, t. 1.

VARELA, João de Matos Antunes. Direito das Obrigações, Rio de Janeiro, Forense, 1977, v. 1.

VIGORITA, Tulio Spagnuolo. Actio Iniuriarum Noxalis. In Labeo Rassegna di Diritto Romano, Nápoles, Jovene, 1969, v. 15-1.

YARSHELL, Luis Flávio. Dano Moral: Tutela Preventiva (ou Inibitória), Sancionatória e Específica, in Revista do Advogado, São Paulo, Associação dos Advogados de São Paulo, n. 49, dezembro de 1996, pp. 61 a 67.

\section{2. Jurisprudência}

Primeira Instância. $7^{a}$ Vara da Fazenda Pública SP, Ação Ordinária de Indenização n. 452/94, j. 9.6.95, juiz Danilo Panizza Filho, São Paulo, jun95.

Primeira Instância. Ação Ordinária, j. 4.7.29, Juiz Laudo Ferreira de Camargo, in Revista dos Tribunais, São Paulo, Ed. Revista dos Tribunais, v. 74, maio1930 , pp. 375 a 377.

Primeiro Tribunal de Alçada Civil. Apelação n. 562.964-5, j. 29.7.94, rel. juiz Carlos Roberto Gonçalves, São Paulo, jul-94.

Primeiro Tribunal de Alçada Civil. Apelação n. 698.188-0 2a C. j. 15.01.97, rel. juiz Alberto Tedesco, in Revista dos Tribunais, São Paulo, Ed. Revista dos Tribunais, v. 740, jun-1997, pp. 308 a 311.

Supremo Tribunal Federal. Autos de embargo n. 1.723, j. 26.6.15, rel. min. Viveiros de Castro, in Revista Forense, Belo Horizonte, Imprensa Oficial do Estado de Minas, v. 24, 1915, pp. 473 a 480.

Supremo Tribunal Federal. Apelação Cível n. 3.585, j. 24.12.20, rel. min. Pedro Lessa, in Revista Forense, Belo Horizonte, Imprensa Official do Estado de Minas Geraes, v. 37, 1921, pp. 201 a 203. 
Supremo Tribunal Federal. Apelação n. 7.526, j. 3.11.42, rel. min. Orozimbo Nonato, in Revista Forense, Rio de Janeiro, Ed. Forense, v. 94, abr-1943, pp. 477 a 481 .

Supremo Tribunal Federal. Recurso Extraordinário n. 12.039, j. 6.8.48, min. rel. Lafayette de Andrada, in Revista Forense, Rio de Janeiro, Ed. Forense, v. 127, jan-1950, pp. 397 a 400.

Supremo Tribunal Federal. Recurso Extraordinário n. $59.940 \quad$ S.P. $2^{\mathrm{a}}$ T., j. 26.4.66, rel. min. Aliomar Baleeiro, in Revista Trimestral de Jurisprudência, s.l., v. 39, jan-1967, pp. 38 a 44.

Supremo Tribunal Federal. Recurso Extraordinário n. 69.754 SP - 2a T., j. 11.5.71, rel. min. Thompson Flores, in Revista Trimestral de Jurisprudência, s.1., v. 57, jan-1971, pp. 787 a 790.

Supremo Tribunal Federal. Recurso Extraordinário n. 71.128 - GB 2ª T., j. 8.5.72, rel. min. Antônio Neder, in Revista Trimestral de Jurisprudência, s.l., v. 62, out-1972, pp. 102 a 105.

Superior Tribunal de Justiça. Recurso Especial n. 23.575 DF, 4 ${ }^{\mathrm{a}}$ T., j. 9.6.97, rel. min. César Asfor Rocha, in Revista dos Tribunais, São Paulo, v. 746, dez1997, pp. 183 a 187.

Superior Tribunal de Justiça. Recurso Especial n. 65.393 RJ, 4 ${ }^{\mathrm{a}}$ T., j. 30.10.95, rel. min. Ruy Rosado de Aguiar, in Revista dos Tribunais, v. 731, set-1996, pp. 226 a 229.

Superior Tribunal de Justiça. Recurso Extraordinário n. 85.123 - SP, $4^{\mathbf{a}}$ T., j. 9.11.76, rel. min. Thompson Flores, in Revista Trimestral de Jurisprudência, s.l., v. 84, jun-1978, pp. 977 a 980.

Tribunal de Alçada do Paraná. Apelação n. 64.605-9 $\quad 3^{\mathbf{a}}$ C, j. 12.4.95, rel. juiz Ivan Bortoleto, in Revista dos Tribunais, Ed. Revista dos Tribunais, v. 723, jan96, pp. 461 a 467.

Tribunal de Alçada do Rio Grande do Sul. Ap. 195.039.094 6 C., j. 20.4.95, rel. juiz Armínio Abreu Lima da Rosa, in Revista dos Tribunais, v. 723, jan-96, pp. 467 a 474.

Tribunal de Justiça de Rondônia. Apelação n. 3.454/94 RO, j. 7.3.95, rel. des. Eurico Montenegro Júnior, in Revista dos Tribunais, v. 724, fev-1996, pp. 425 a 428. 